Radosław Kuliniak

Uniwersytet Wrocławski

e-mail: kornik90@poczta.onet.pl

\title{
Przegląd wykładów, ćwiczeń i seminariów akademickich Kazimierza Twardowskiego z filozofii nowożytnej
}

DOI: http://dx.doi.org/10.12775/RF.2017.007

\section{Wstęp}

Wśród lwowskich wykładów akademickich Kazimierza Twardowskiego należy odnotować siedem jedno- i dwusemestralnych odczytów z historii filozofii nowożytnej. Wygłaszał je w latach 1896/1897, 1903/1904, 1904/1905, 1909/1910, a także 1922/1923. Wpisują się one doskonale w całość badań i zajęć dydaktycznych z filozofii nowożytnej prowadzonych przez niego na Uniwersytecie Lwowskim. Obok Twardowskiego na tej uczelni wykładali: Aleksander Skórski, Mścisław Wartenberg, Aleksander Raciborski, Wojciech Dzieduszycki, Jan Łukasiewicz, Roman Witold Ingarden i wielu innych polskich filozofów. Podczas wykładów, jak również ćwiczeń i seminariów, dokonywali oni wraz ze studentami analizy oraz interpretacji tekstów takich myślicieli, jak Condillac, Locke, Hume, Berkeley, Descartes, Leibniz, Kant, Schelling, Fichte, Hegel, czy też Schopenhauer. Były to zajęcia na niezwykle wysokim poziomie, wymagającym od studenta znajomości języków obcych, łaciny i greki. Twardowski zaraz po objęciu we Lwowie w 1895 roku Katedry Filozofii starał się z wyprzedzeniem konsultować i układać stosowny plan tych zajęć. Następnie władze wydziałowe i uniwersyteckie zatwierdzały i przyjmowały plan do realizacji oraz publikacji w zeszytach akademic- 
$\mathrm{kich}^{1}$. Uczestniczący w zajęciach studenci z zapałem przyswajali analizowane treści, a wykładowcy nie rywalizowali ze sobą, lecz starali się bezstronnie przekazywać im swoją wiedzę.

Do lwowskich wykładów akademickich Twardowskiego z obszaru historii filozofii nowożytnej zaliczamy: 1) Filozofię wieku XIX, wykład w semestrze letnim 1896/1897; 2) Dzieje filozofii nowożytnej w zarysie, wykład w semestrze letnim 1902/1903. Niestety te dwa wykłady nie zachowały się2. Ponadto wymienia się: 3) Rozwój filozofii w XIX wieku (Kant, Fichte, Schelling), tj. cykl wykładów w semestrze zimowym 1903/1904; 4) Filozofia francuska XIX wieku, tj. cykl wykładów w semestrze letnim 1903/1904; 5) Filozofia Hegla, tj. dwa cykle wykładów w semestrze zimowym i letnim 1904/1905; 6) Rozwój filozofii nowożytnej do Kanta, tj. dwa cykle wykładów w semestrach zimowym i letnim 1909/1910; oraz 7) Rozwój filozofii nowożytnej, tj. również dwa cykle wykładów w semestrach zimowym i letnim 1922/1923. Należy pamiętać, że nie są to gotowe teksty przeznaczone do publikacji. Twardowski swoje wykłady starał się prowadzić bardzo dokładnie. Odznaczają się one niezwykłą przenikliwością. Dokonywał on drobiazgowej i wnikliwej analizy, aby móc przekazać studentowi jak najwięcej wiedzy. Nigdy nie zostawiał studenta samego z trudnym tekstem. Filozofia stanowiła dla niego swoiste pole doświadczalne dla wciąż kształconego „popisu” myślenia. Student miał się wykazać, ale i wykładowca musiał zrobić wszystko, aby student mógł wyjść z wykładu za każdym razem nie tylko zadowolony, lecz spełniony. Student otrzymywał wiedzę i wskazówki. Twardowski miał w zwyczaju układać program zajęć dydaktycznych, wskazując możliwe obszary zagadnień do studiowania.

Rękopisy i maszynopisy tych wykładów Twardowskiego, złożone w Archiwum Połączonych Bibliotek WFiS UW, IFiS PAN i PTF oraz Polskiej Akademii Nauk Archiwum w Warszawie, Archiwum Kazimierza Twardowskiego, wskazuja, że materiał archiwalny nie jest uporządkowany. Są to teksty co prawda ukształtowane „ręką" Twardowskiego, lecz mamy do czynienia tylko i aż z jego wykładami. Trzeba też pamię-

1 Zob. Wykazy wykładów odbywać się majacych w C. K. Uniwersytet imienia Cesarza Franciszka I. we Lwowie. Skład Uniwersytetu i program wykładów z lat 1876-1939. Zaznaczmy, że od roku akademickiego 1919/1920 wykazy te dotyczyły Uniwersytetu w Lwowie im. Jana Kazimierza. Ukazywały się one dwa razy lub raz do roku przed semestrem zimowym i letnim. Część numerów zawiera propozycje wykładów i innych zajęć zgodnie z podziałem na poszczególne trymestry. W naszych analizach staramy się trzymać podziału rocznego na dwa semestry: zimowy i letni.

2 Wszystkie prezentowane wykłady pochodzą z Archiwum Połączonych Bibliotek WFiS UW, IFiS PAN i PTF oraz Polskiej Akademii Nauk Archiwum w Warszawie, Archiwum Kazimierza Twardowskiego. Wykłady gromadzone w tym archiwum są wstępnie skatalogowane i opisane. Mają zatem swoją stosowną sygnaturę. Te oznaczenia podajemy przy każdym wykładzie. 
tać, że tworzył on swoje wykłady na podstawie stosownych komentarzy dobieranych do tekstów źródłowych. Czytał przede wszystkim teksty oryginalne Bacona, Descartesa, Spinozy, Locke'a, Hume'a, Berkeleya, Kanta, Fichtego, Schellinga, czy też Hegla, a następnie komentował je, sięgając do komentarzy Erdmanna, Hayma, Falckenberga, Fischera, Rosenkranza, Windelbanda i wielu innych. Analizował te teksty, zgłębiając swoją wiedzę o danym filozofie i jego poglądach. Nie zważając na liczne problemy, sięgał do trudnych i kontrowersyjnych komentarzy, które $\mathrm{w}$ merytoryczny i w nowy sposób odsłaniały dane zagadnienie w duchu rzetelnie uprawianej historii filozofii. Wykłady Twardowskiego z XVII, XVIII i XIX-wiecznej filozofii są jedynymi w swoim rodzaju tekstami historyczno-filozoficznymi w obszarze całej polskiej literatury filozoficznej, w których krok po kroku w sposób merytoryczny i systematyczny zostały przedstawione problemy konieczne dla zrozumienia filozofii Bacona, Descartesa, Spinozy, Locke'a, Hume'a, Berkeleya, Kanta, Fichtego, Schellinga i Hegla. Nie ma w naszych polskich badaniach nad XVII, XVIII i XIX-wieczną filozofią drugiej tak pieczołowicie wykonanej pracy historyczno-filozoficznej. Wykłady te ujawniają doskonały warsztat Twardowskiego jako historyka filozofii. Drobiazgowa dążność do tego, aby problem rozważać jak najgłębiej sprawia, że lektura tekstu staje się przyjemna i ciekawa, a w znacznej części pokazuje, jak dziś należy prowadzić badania $\mathrm{w}$ zakresie historii filozofii. Wręcz idealny pozostaje przy tym dobór komentarzy do filozofii Bacona, Descartesa, Spinozy, Locke'a, Hume'a, Berkeleya, Kanta, Fichtego, Schellinga i Hegla. Pokazuje wszechstronność zainteresowań Twardowskiego, który nie stronił od podejmowania trudnych problemów z obszaru XVII, XVIII i XIX-wiecznej filozofii. Był jej doskonałym znawcą. Twardowski wiedział doskonale o tym, że filozofia polska, zwłaszcza ta XIX-wieczna, nie abstrahuje i nie odcina się całkowicie od filozofii niemieckiej, angielskiej, czy też francuskiej. Co więcej, przygotowując swoje wykłady, uzależniał on jej rozwój i prezentację od dokładnego rozpoznania kolejnych wpływów oraz oddziaływań. W źródłowej analizie tekstów Bacona, Descartesa, Spinozy, Locke'a, Kanta, Fichtego, Schellinga i Hegla oraz istotnych komentarzy do nich interesowały go chociażby przejście od filozofii Kanta do filozofii idealizmu niemieckiego oraz relacje między Kantem, Fichtem, Schellingiem i Heglem. Te kwestie, zdaniem Twardowskiego, zaważyły na rozwoju filozofii polskiej w XIX wieku. 


\section{Przegląd zajęć dydaktycznych z filozofii nowożytnej na Uniwersytecie Lwowskim w latach 1876-1939}

Zajęcia z filozofii nowożytnej zajmują ważne miejsce $\mathrm{w}$ dydaktyce prowadzonej na Uniwersytecie Lwowskim w latach 1876-1939. Wśród wykładających tam filozofów wymienia się najczęściej: Euzebiusza Czerkawskiego, Juliana Leopolda Ochorowicza, Aleksandra Skórskiego, Kazimierza Twardowskiego, Mścisława Wartenberga, Aleksandra Raciborskiego, Jana Łukasiewicza, Wojciecha Dzieduszyckiego, Romana Witolda Ingardena i wielu innych. Prezentowali oni filozofię nowożytną i współczesną podczas swoich wykładów, ćwiczeń z lekturą i interpretacją tekstów, a także na zajęciach seminaryjnych. Były one stale obecne w kolejnych latach ich aktywności akademickiej ${ }^{3}$.

Filozofię nowożytną wykładano na Uniwersytecie Lwowskim od początku jego istnienia ${ }^{4}$. Wśród jej prekursorów prowadzących wykłady z tego właśnie zakresu należy wskazać przede wszystkim Euzebiusza Czerkawskiego, który w letnim półroczu 1876/1877 wygłaszał swój wykład o Systematach Fichtego i Schellinga. Rok później w semestrze zimowym wykład z Dziejów filozofii przyrody od Arystotelesa do Bacona prowadził Julian Leopold Ochorowicz. Wykładał on również Psychologie niemiecka w XIX wieku w roku akademickim 1879/1880 w semestrze letnim. Z kolei w semestrze letnim 1884/1885 dołączył do nich Aleksander Raciborski, który prowadził wykład pt. Zarys historii filozofii pod koniec wieku XVII, a kilka lat później w semestrze letnim 1893/1894 podjął się Objaśnienia utylitaryzmu Milla.

Twardowski we Lwowie pojawił się w roku akademickim 1895/1896 i zaczął wykładać w semestrze zimowym. Prowadził wówczas wykład z Logiki. Zimą tego roku wykładali również Skórski i Dzieduszycki. Pierwszy prowadził lekturę i dokonywał interpretacji Medytacji De-

3 Działalność akademicką lwowską, zwłaszcza podział na katedry, seminaria, ćwiczenia oraz samą strukturę prowadzonych tam zajęć, opisuje I. Dąmbska w Filozofia na Uniwersytecie Jana Kazimierza we Lwowie, "Zeszyty Lwowskie”, 1971, nr 2, s. 76-90.

4 Przeglądu wykładów i innych zajęć z filozofii nowożytnej Twardowskiego tudzież i innych filozofów dokonuję na podstawie Wykazów wykładów odbywać się majacych w C. K. Uniwersytet imienia Cesarza Franciszka I. we Lwowie. Skład Uniwersytetu i program wykładów z lat 1876-1939. Korzystam też z publikacji R. Jadczaka Kazimierz Twardowski. Nota bibliograficzna, „Spis wykładów i seminariów Kazimierza Twardowskiego w Uniwersytecie Lwowskim", Toruń 1991, s. 59-77. W wykazie nie ma konkretnych wskazań i odniesień do tych publikacji. Powstający bowiem w tej mierze nadmiar przypisów zakłócałby jasność przeglądu. Staram się jedynie podać rok akademicki oraz konkretny semestr lub trymestr dla wymienianych zajęć. 
scartesa ${ }^{5}$. Drugi zaś wykładał Historię filozofii średniowiecznej $i$ nowożyt$n e j$. Twardowski natomiast w semestrze letnim proponował studentom Przeglad krytyczny dziejów filozofii od czasów najdawniejszych do końca wieku XVIII, a swój wykład na temat Rozwoju filozofii w XIX stuleciu prezentował Skórski ${ }^{6}$.

W kolejnym roku akademickim 1896/1897 w semestrze zimowym Skórski prowadził zajęcia z Krytyki czystego rozumu, a wykład z Historii filozofii w Anglii prezentował Dzieduszycki. Twardowski z kolei zaczął czytać wraz ze studentami podczas tzw. „ćwiczeń z dyskusją" dzieło Condillaca, tj. Traktat o wrażeniach zmystowych ${ }^{7}$. W semestrze letnim Skórski prowadził natomiast Krytyczna analize filozofii Kanta jako wstępu do studiów filozoficznych, a Twardowski podjął wykład z Filozofii wieku XIX. Wykład ten nie zachował się wśród materiałów archiwalnych.

W semestrze zimowym w roku akademickim 1897/1898 Skórski wykładał podstawy Etyki Kanta. Twardowski w ramach seminarium filozoficznego podjął "wspólną lekturę" dzieła Berkeleya Rzecz o zasadach poznania na podstawie polskiego przekładu Feliksa Jezierskiego ${ }^{8}$. W tym samym semestrze Dzieduszycki prowadził wykład zatytułowany Pozytywizm nowożytny.

Kolejne lata działalności akademickiej filozofów we Lwowie przyniosły ze sobą następne zajęcia poświęcone filozofii nowożytnej. Zimą

5 Skórski zajęcia te powtarzał także w roku akademickim 1898/1899 w semestrze zimowym podczas swojego seminarium filozoficznego.

6 Wykład ten Skórski powtarzał w roku akademickim 1899/1900 w semestrze letnim.

7 Prace na seminariach Twardowskiego musiały być przygotowywane na podstawie lektury dzieł oryginalnych. Można było niekiedy tylko korzystać z przekładów polskich, ale podstawą wszelkich odniesień był tekst oryginalny. W przypadku dzieła Condillaca opierał się on na Traité des Sensations, À Madame la Comtesse de Vassé par M. L'Abbé de Condillac, 1754, w: CEuvres complètes Condillac, édition Lecointe et Durey, 1821-1822. Pomocny jest natomiast polski przekład tej pracy: Kondylak, Traktat o wrażeniach zmysłowych, z francuskiego przełożył A. Lange, red. H. Struve, „Biblioteka Filozoficzna”, Skład główny w Księgarni E. Wendego i S-ki, Warszawa 1887. Zob. też E. B. de Condillac, Logika czyli pierwsze zasady sztuki myślenia, przeł., uzup. i oprac. Jan Znosko, Wilno 1802.

8 Lekturę tego tekstu Berkeley'a Twardowski zaleca na podstawie pierwszego przekładu niemieckiego Ueberwega. Zob. George Berkeley's Abhandlung über die Principien der menschlichen Erkenntnis, Erstdruck: Dublin 1710, Der Text folgt der ersten deutschen Übersetzung durch Friedrich Ueberweg von, Berlin 1869. Studenci mogli też korzystać z przekładu polskiego. Zob. G. Berkeley, Rzecz o zasadach poznania ludzkiego, przekład Feliks Jezierski, red. H. Struve, „Biblioteka Filozoficzna”, Skład główny w Księgarni E. Wendego i S-ki, Warszawa 1890. Szerzej o polskich badaniach nad filozofią brytyjskiego empiryzmu piszemy w: R. Kuliniak i D. Leszczyna, Polskie badania nad filozofią brytyjskiego empiryzmu (lata 1760-1918), cz. I, „Studia z Historii Filozofii", 2012, nr 3, s. 115-122. 
1898/1899 Twardowski podjął lekturę i interpretację w oryginale rozprawy Schopenhauera Ueber die Freiheit den menschlichen Willens.

Latem natomiast w roku akademickim 1899/1900 Skórski prowadził wykład z Filozofii XIX wieku.

Twardowski w semestrze zimowym 1900/1901 podjął po raz pierwszy lekturę $\mathrm{i}$ interpretację $\mathrm{w}$ ramach seminarium filozoficznego niższego Descartesa Meditationes de prima philosophia. W obu też semestrach 1900/1901 na seminarium filozoficznym niższym prowadził systematyczną lekturę i interpretację dzieła Hume'a Szkic o rozumie ludzkim9 a w semestrze letnim 1900/1901 i semestrze zimowym 1901/1902 w ramach seminarium filozoficznego wyższego lekturę i interpretację Kantowskich Prolegomenów do wszelkiej przyszłej metafizyki, która będzie mogła wystapić jako nauka. Czytał tekst oryginalny. Nadmieńmy, że Twardowski znał już w tym czasie pierwszy polski przekład tego dzieła Romualda Grzymały-Piątkowskiego, wydany pod redakcją Henryka Struvego. Śledził też dokładnie polemikę wokół niego między Herszem Badem a Piątkowskim i Struvem ${ }^{10}$.

W semestrze zimowym 1902/1903 Twarowski czytał i komentował w seminarium filozoficznym niższym ponownie dzieło Berkeleya Rzecz $o$ zasadach poznania. $\mathrm{W}$ ramach tego samego seminarium, tym razem w semestrze letnim, czytał Hume'a Rozprawy o rozumie ludzkim. Z kolei $\mathrm{w}$ seminarium filozoficznym wyższym $\mathrm{w}$ semestrze zimowym sięgnął po oryginał pracy Schopenhauera Ueber das Fundament der Moral. W tym samym jeszcze roku akademickim w semestrze letnim podjął zaś drugi z kolei swój wykład z filozofii nowożytnej. Są to Dzieje filozofii nowożytnej $w$ zarysie. Niestety wśród materiałów archiwalnych wykład ten, podobnie jak odczyt z Filozofii wieku XIX, nie zachował się.

W semestrze zimowym 1903/1904, obok interpretacji fragmentów z Krytyki czystego rozumu w seminarium wyższym, czytał Twardowski ze studentami w seminarium niższym ponownie Hume'a Rozprawy o rozumie ludzkim. Zdawał sobie przy tym doskonale sprawę z tego, że wpływ Hume'a na Kanta jest sprawą zasadniczą a zrozumienie Krytyki czystego rozumu bez znajomości Rozpraw o rozumie ludzkim oraz innych prac Hu-

9 Tytuł dzieła Hume’a może być tutaj nieco mylący. Chodzi bowiem o pierwszą część jego Traktatu o naturze ludzkiej, a mianowicie o rozważania z t. I. „O rozumie”. To ona była przedmiotem rozważań Twardowskiego wraz ze studentami podczas seminarium filozoficznego. W późniejszym czasie w latach 1910/1911 na seminarium Twardowski czytał, jak jest podane w różnych spisach jego wykładów i zajęć seminaryjnych, Traktat o naturze ludzkiej.

10 Szerzej o tej polemice piszą: R. Kuliniak i D. Leszczyna w Spory wokót polskich przekładów dzieł Immanuela Kanta z lat 1795-1918, „Cz. I. Polemiki wokół dawnych polskich przekładów Kantowskich »Prolegomenów do wszelkiej przyszłej metafizyki, która będzie mogła wystąpić jako nauka«, Wrocław 2015, ss. 221 (zawiera wybór tekstów dotyczący tej polemiki). 
me'a, w tym Badań dotyczacych rozumu ludzkiego, wydaje się niemożliwe. Dodajmy, że w ramach seminariów filozoficznych niższego i wyższego Twardowski prezentował fragmenty przekładu Badań, którego dokonał wraz z Janem Łukasiewiczem, a które ukazały się drukiem w 1905 roku ${ }^{11}$. Ponowną lekturę Hume'a Rozpraw o rozumie ludzkim Twardowski podjął w semestrze letnim 1903/1904. Była to kontynuacja i dokończenie zajęć z poprzedniego semestru. Odbywały się one również w seminarium niższym. Z kolei w semestrze zimowym i letnim 1903/1904 w ramach seminarium filozoficznego wyższego proponował on lekturę i interpretację wybranych fragmentów z Krytyki czystego rozumu. Korzystał z oryginału niemieckiego, tudzież za zgodą Piotra Chmielowskiego prezentował fragmenty jego przekładu Krytyki czystego rozumu.

We wspomnianym semestrze zimowym 1903/1904 Twardowski podjął kolejny swój wykład z filozofii nowożytnej. Był nim Rozwój filozofii $w$ XIX wieku ${ }^{12}$. Od samego początku zapowiadał się on niezwykle interesująco. Liczne grono słuchaczy spodziewało się usłyszeć cykl ogólnych wykładów Profesora z historii filozofii nowożytnej. Sam Twardowski nie był jednak o tym do końca przekonany. Musiał rozwiązać kilka istotnych problemów. Na pewno nie miał zamiaru wykładać filozofii nowożytnej, ograniczając się do prezentacji poglądów Descartesa, Spinozy, Malebranche'a, Pascala, czy też empiryków brytyjskich: Locke'a, Hume'a i Berkeleya. Przypomnijmy, że niektóre z tych zagadnień ujął już we wcześniejszym swoim wykładzie w semestrze letnim 1895/1896, tj. w Przegladzie krytycznym dziejów filozofii od czasów najdawniejszych do końca wieku XVIII'13, a także w zaginionych dwóch ogólnych wykładach z filozofii nowożytnej z lat 1896/1897 i 1902/1903. Osobnym problemem stała się dla niego w tym momencie filozofia Kanta i jej recepcja w XVIII

11 Zob. D. Hume, An Enquiry concerning Human Understanding, w: idem, Essays Moral, Political, and Literary by David Hume, ed. by T. H. Green and T. H. Grose, London 1898. Tekst ten stał się podstawą polskiego tłumaczenia Badań dotyczacych rozumu ludzkiego, przeł. J. Łukasiewicz, K. Twardowski, Polskie Towarzystwo Filozoficzne, Lwów 1905. Dodajmy też, że wcześniej próbę przekładu dzieła Hume’a na zlecenie Struvego podjął Antoni Lange. Jego przekład dwóch rozdziałów X i XI z dzieła Huméa ostatecznie został jednak przez Struvego odrzucony.

12 Zob. Filozofia w XIX. 1. "Rozwój filozofii w XIX. wieku, rok akademicki 1903/04, semestr zimowy, (obejmuje głównie: filozofię I. Kanta, J. G. Fichtego, F. W. J. Schellinga), k. 1-45, nr spisu inw. P. 1,3. Dalej przez nas cytowany jako Rozwój filozofii w XIX wieku (Kant, Fichte, Schelling).

13 Zob. Przegląd krytyczny dziejów filozofii od czasów najdawniejszych do końca wieku XVIII, kurs letni 1896. Rok akademicki 1895/6, semestr letni, 3 godz. tygodniowo od 12-13 godz., rkps. z licznymi odręcznymi i maszynowymi dopiskami i poprawkami, $21 \times 17$ cm., k. 210, luźne, 1. Tekst wykładu, k. 1-210; 2. Notatki do filozofii starożytnej, k. 211, nr spisu inw. P. 1,1. 
i XIX wieku na gruncie filozofii niemieckiej ${ }^{14}$. Już w pierwszych zamysłach Twardowskiego powstał skrzętnie zaplanowany zarys tych wykładów. Ich przygotowaniu miały służyć dwa inne jego wystąpienia. Pierwszym był wykład prezentowany w sali Rady Miejskiej we Lwowie 14 marca 1902 roku podczas sesji: „Wiedza i Życie w XIX stuleciu”. Nosił on tytuł: Filozofia XIX wieku. Historia filozofii od XVII wieku (Kartezjusz) ${ }^{15}$. Streszczenie tego wykładu ukazało się w nr. 80 „Kuriera Lwowskiego” z 1902 roku na s. $7^{16}$. Liczy on 61 stron, tj. odręcznie prowadzonych zapisków na temat XVIII-wiecznej filozofii, a także w sprawie filozofii Kanta oraz przejścia od niej do filozofii niemieckiego idealizmu. Całość została zakończona uwagami na temat historii logiki w Polsce, czynionymi bezpośrednio za wskazaniami Struvego ${ }^{17}$. Drugie natomiast wystąpienie, a dokładnie cykl wykładów o XIX-wiecznej filozofii niemieckiej, był przez Twardowskiego prezentowany w Zakopanem na uniwersytecie wakacyjnym w ramach spotkań Towarzystwa Wyższych Kursów Wakacyjnych: „Polska Nauka”. Celem Towarzystwa była organizacja kursów letnich, mających na celu wygłaszanie prelekcji naukowych w języku polskim z różnych dziedzin nauki. Inauguracja cyklu odczytów odbyła się 30 lipca 1904 roku $^{18}$. Wśród nich znalazły się także wykłady Twardowskiego pt. Główne prady w filozofii XIX ${ }^{19}$. Spis tych wykładów

14 Niezwykle pomocna $\mathrm{w}$ tym względzie okazuje się przy rozpoznaniu recepcji XVIII i XIX-wiecznej filozofii niemieckiej w filozofii polskiej praca Struvego pt. Wykład systematyczny logiki czyli Nauka dochodzenia i poznania prawdy (t. 1: Część wstępna, Warszawa 1870). Twardowski podjął za nim analizę wpływów XIX-wiecznej filozofii niemieckiej na filozofię polska, zwłaszcza wpływ dyskusji i sporu Schellinga z filozofią Hegla, na podstawie analizy prac polskich myślicieli - zwolenników Schellinga i zwolenników Hegla.

15 Zob. Filozofia XIX w. Historia filozofii od XVII w. (Kartezjusz), (prawdopodobnie odczyt wygłaszany 14 marca 1902 r. we Lwowie, w sali obrad Rady Miejskiej w cyklu „Wiedza i Życie w XIX stuleciu”), V, k. 61; Rękopis z odręcznymi dopiskami; Karty luźne; 1. Tekst odczytu, k. I-V, 1-60 - 2. Notatki, k. 61.

16 Zob. „Kurier Lwowski”, nr 80 z 21 marca 1902 roku, s. 9 (błędnie oznaczona jako s. 7).

17 Zob. H. Struve, Wykład systematyczny logiki czyli Nauka dochodzenia i poznania prawdy, zwłaszcza „II. Rys historii i literatury logiki, § 13. Trzecia epoka najnowszej filozofii, począwszy od Kanta", s. 99-117; „§ 14. Najnowszy stan logiki”, s. 117-132; „Logika w Polsce”, s. 132-183.

18 Zob. szerzej o tym traktuje J. Kurjata w Towarzystwo Wyższych Kursów Wakacyjnych "Polska Nauka", w: Stownik polskich towarzystw naukowych, t. 2: Towarzystwa naukowe i upowszechniające naukę działajace w przeszłości na ziemiach polskich, cz. 3, red. B. Sordylowa, Warszawa 2001, s. 504-506, zwłaszcza cyt. s. 505.

19 Zob. ibidem, jak też: R. Jadczak, Kazimierz Twardowski. Nota bibliograficzna, s. 18. Cykl wykładów Twardowskiego obejmuje 6 jednogodzinnych odczytów, jak także dodatkowo jedną godzinę konwersatorium. Zob. A. Haratyk, Uniwersytet Wakacyjny w Zakopanem jako jedno ze źródeł łaczności i edukacji kulturalnej Polaków w okresie zaborów, w: Edukacja wobec wielokulturowości. Księga jubileuszowa ofiarowana profesorowi Januszo- 
był drukowany w „Programach Powszechnych Wykładów Uniwersyteckich" we Lwowie, Rok VI. Seria I., listopad i grudzień 1904. Wśród nich na szczególną naszą uwagę zasługują następujące wystąpienia: II. a) Monizm spirytualistyczny czyli idealistyczny (Fichte), b) Wskrzeszenie monizmu spinozystycznego (Schelling) ${ }^{20}$.

Wróćmy jednak do wykładów z Rozwoju filozofii w XVIII i XIX wie$k u$. Twardowski 14 marca 1902 roku w sali Rady Miejskiej we Lwowie wygłosił wykład z Filozofii XIX wieku. Historia filozofii od XVII wieku (Kartezjusz). Na podstawie tego wystąpienia powstały notatki, w których rozpisana została treść jego przyszłych wykładów akademickich o XVIII i XIX-wiecznej filozofii niemieckiej (zwłaszcza relacji na linii Kant-Fichte-Schelling). Ich lektura rzuca światło na prowadzone przez niego $\mathrm{w}$ tym zakresie przygotowania. Ujawnia skrzętnie sporządzony i realizowany plan. Znamienne pozostają już pierwsze zdania z ogólnego pierwszego „Wstępu". Wyłożona tam została wiodąca tendencja badań filozoficzno-historycznych. „Fil. w XIX. - pisze Twardowski - niejednym płynie korytem; niejeden szereg następujących po sobie myślicieli: Anglia, Niemcy, Francja, Włochy. - Dalej: nieodrębne całości dla siebie, lecz w związku najściślejszym z XVIII wiekiem w dalszym rozwoju wielkie przełomy [tylko] z chwilą nowego wieku; właściwy przełom [dokonuje się] w wieku XVIII - wiek XIX tylko [jego] konsekwencje [nosi]: różne form i tu epoki. - Naszym zadaniem pozyskać przegląd na główne prą-

wi Sztumskiemu, red. M. Jakunowicz, K. Rędziński, Częstochowa 2002, s. 81). Zajęcia prowadzone są w hotelu „Morskie Oko” przez tydzień, bez niedzieli. Wykłady odbywały się przed południem, a konwersatorium po południu. Zob. Z. E., Uniwersytet wolny w Zakopanem, „Słowo Polskie”, nr 364 z 4 sierpnia 1904 roku, s. 2-3 (korespondencja, datowana na 2 sierpnia 1904 r., sporządzona zostaje w trakcie trwania zajęć).

20 Zob. K. Twardowski, Rozprawy $i$ artykuty filozoficzne, Lwów 1927, s. 442-443 („Główne prądy w filozofii wieku XIX. Program wykładów”). Jest to program wykładów z cyklu „Powszechne Wykłady Uniwersyteckie”, (XI-XII-1904). Zob. też zapowiedzi wystąpień Twardowskiego w "Słowo Polskie”, nr 530 z 11 listopada 1904 roku (wyd. poranne), s. 1: „Odczyty i wykłady: Wykłady powszechne Dr. Twardowski: Główne prądy w filozofii XIX w.” (Sala XIV. Uniw.) o g. 71122); „Słowo Polskie”, nr 542 z 18 listopada 1904 roku (wyd. poranne), s. 1: „Odczyty i wykłady: Wykłady powsz. Dr. Twardowski: Główne prądy w filozofii 19 w.” (Sala XIV. Uniw.) o 7.30 w.; „,Słowo Polskie”, nr 554 z 25 listopada 1904 roku (wyd. poranne), s. 1: „Odczyty i wykłady: Wykłady powszechne Dr. Twardowski: Główne prądy w filozofii XIX w." (Sala XIV. Uniw. o 7:30)”. „Słowo Polskie”, nr 577 x 9 grudnia 1904 roku (wyd. poranne), s. 1: „Odczyty i wykłady: Wykłady powszechne Dr. Twardowski: Główne prądy w filozofii XIX w.” (Sala XIV. Uniw. o 7:30); „Słowo Polskie”, nr 597 z 21 grudnia 1904 roku (wyd. poranne), s. 1: „Odczyty i wykłady: Wykłady powszechne Dr. Twardowski: Główne prądy w filozofii XIX w.” (Sala XIV. Uniw. o 7:30). „Słowo Polskie”, nr 598 z 21 grudnia 1904 roku (wyd. popołudniowe), s. 5: „Wykłady powszechne. Zapowiedziany na dziś w „kalendarzu” numeru porannego wykład prof. dra Twardowskiego pt. „Główne prądy w filozofii XIX w." nie odbędzie się z powodu, iż już rozpoczęły się ferie świąteczne". 
dy, zdać sobie sprawę z dokonań, zrozumieć w czym XVIII wiek postąpił wobec dawniejszych. Ale programu tego wyczerpać nie możemy w jednym słowie. Dlatego ograniczenie: filozofia francuska i angielska, niemiecka zaś [dopiero] później - zresztą ona i tak głównie arbitralną [pozostaje] kosztem francuskiej i angielskiej" ${ }^{21}$. W tym czasie Twardowski pozostał jeszcze przy pomyśle omówienia całej filozofii nowożytnej. Z chwilą przygotowywania wykładu na semestr zimowy 1903/1904 wyraźnie oddzielił jednak XVIII i XIX-wieczną filozofię niemiecką od innych nurtów filozofii nowożytnej. Przeniósł też do semestru letniego 1903/1904 wykład na temat XVIII i XIX-wiecznej filozofii francuskiej². Podobnie uczynił z omówieniem Krytyki czystego rozumu i Krytyki praktycznego rozumu, przenosząc ich prezentację do zajęć w seminarium filozoficznym wyższym.

Treść pierwszej części wykładu z Rozwoju filozofii w XVIII i XIX wieku, tj. omówienie Krytyki władzy sadzenia, jako ogniwa łączącego i prowadzącego do idealizmu niemieckiego, wsparta została przez Twardowskiego na rozważaniach Wilhelma Windelbanda z Die Geschichte der neueren Philosophie, t. II, wyd. drugie, 1899, s. 148-17323. Nie skupiał się on jedynie na możliwości ukazania bezpośredniego przejścia od Kanta do idealizmu niemieckiego. Starał się wskazać w bliższy sposób tę zależność. Nie ulegał prostemu zafascynowaniu, jakoby można było zrozumieć dwie pierwsze Krytyki Kanta, rozpoczynając lekturę od trzeciej w kolejności Krytyki władzy sadzenia. Ten zamiar jest pierwotnie przypisywany Fichtemu. Tego typu postępowanie, zdaniem Twardowskiego, może przynieść jedynie pozór dobrego uprawiania historii filozofii. Prawdziwe i rzetelne podejście do własnych obowiązków polega raczej na studiowaniu poglądów wielkich filozofów na podstawie źródeł oraz przy wsparciu na rzeczowych komentarzach. Dzieło Windelbanda dało Twardowskiemu podstawy do uzasadnienia po Kancie rozwoju całej niemieckiej filozofii idealistycznej. Uznał on, że potrzebny jest młodzieży studiującej we Lwowie wykład o filozofii Kanta i jej wpływie na filozofię idealistyczną

21 Zob. Filozofia XIX wieku. Historia filozofii od XVII wieku (Kartezjusz), „Wstęp” (pierwszy), s. 1.

22 Zob. Filozofia francuska wieku XIX. Półrocze letnie 1903-1904. Tekst w języku polskim, k. 39, luźnych, formatu $21 \times 17 \mathrm{~cm}$. Pismo maszynowe, jednostronne, nr inw., P. 1,4. Wykład ten przedstawia i zawiera omówienie francuskiego sensualizmu oraz kierunków i postaci pokrewnych.

23 W. Windelband, Die Geschichte der neueren Philosophie in ihrem Zusammenhange mit der allgemeinen Cultur und den besonderen Wissenschaften, Bd. 2, Die Blüthezeit der deutschen Philosophie. Von Kant bis Hegel und Herbart, Leipzig 1880 (2. Aufl. 1899), „II. Teil, Die Kantische Philosophie, § 61. Kants ästhetische Philosophie”, s. 146-173. Twardowski czytał i korzystał też z innych prac Windelbanda. Są wśród nich rozważania Über die verschiedenen Phasen der Kantischen Lehre vom Ding-an-sich, „Vierteljahrsschrift für wissenschaftliche Philosophie", Bd. 1, 1877, s. 224-266. 
Fichtego i Schellinga. Dotyczył on tzw. opcji pośredniej między Kantem a Heglem, do której zaliczały się między innymi ustalenia Jacobiego i Reinholda. Miało to dopełnić zarówno lekturę i interpretację Kantowskich Krytyk dokonywanych w ramach seminarium filozoficznego wyższego, jak i wskazać drogę jej dalszej recepcji.

Wykład Twardowskiego rozpoczął się od omówienia założeń zawartych w Krytyce władzy sadzenia. Oparł on swoje rozważania na wspomnianym już komentarzu Windelbanda. Było to posunięcie doskonale przemyślane. Twardowski dostrzegał u Windelbanda interpretację otwartą na filozofię Kanta, jak i na filozofię niemieckiego idealizmu, głównie Fichtego i Schellinga. U Windelbanda nastąpiło bowiem zderzenie filozofii Kanta z filozofią Fichtego oraz przejście od Kanta przez Schellinga do Hegla. Postulował on jednoczesny „powrót” do tych wielkich filozo$\mathrm{fii}^{24}$. Jeśli chodzi o zderzenie filozofii Kanta i Fichtego, to Windelband położył nacisk na ważność Kantowskich postanowień praktycznego rozu$\mathrm{mu}^{25}$. Wśród innych obszarów, obok krytyki Kantowskiego stanowiska o rzeczy samej w sobie ${ }^{26}$, akcentował relacje Kanta z Schellingiem. Należy rozpoznać zwłaszcza obszar wolności, jako „,indywidualnej moralności i celu kierującego naszym całym życiem" ${ }^{27}$. U Windelbanda padło ponadto ważne stwierdzenie, że „nasza historia wolności jest jednocześnie historią ludzka, powszechna, historią jako procesem zewnętrznego współżycia istot rozumnych" ${ }^{28}$. Tym samym pozostał już niewielki krok od Kanta w stronę filozofii Hegla. Dla niego zarówno Kant, jak i Hegel, są filozofami swoich czasów, a nasze zainteresowania mają charakter akceptujący osiągnięcia każdego z nich z osobna. Windelband doko-

24 Zob. wykład wygłoszony przez Windelbanda w 1881 roku, który wszedł w skład pierwszego wydania jego Präludien. Zob. W. Windelband, Immanuel Kant. Zur Säkularfeier seiner Philosophie, w: idem, Präludien. Aufsätze und Reden zur Einleitung in die Philosophie, Freiburg i B. - Tübingen 1884. Korzystam z wydania trzeciego z 1907 roku, s. 135-169. Szerzej o tym w polskiej literaturze filozoficznej pisze A. J. Noras w Historia neokantyzmu, (Prace Naukowe Uniwersytetu Śląskiego w Katowicach 2965) Katowice 2012, „Część druga, Rozwój, 12. Szkoła badeńska, 12.1. Wilhelm Windelband", s. 453-462.

25 Zob. W. Windelband, Die Geschichte der neueren Philosophie, Bd. 2, Die Blüthezeit der deutschen Philosophie. Von Kant bis Hegel und Herbart, „II. Teil, Die Kantische Philosophie, § 61. Kants ästhetische Philosophie", s. 146-173. Zob. też uwagi A. J. Norasa w Historia neokantyzmu, s. 469-471.

26 W. Windelband, Über die verschiedenen Phasen der Kantischen Lehre vom Ding-an-sich, „Vierteljahrsschrift für wissenschaftliche Philosophie”, Bd. 1, 1877, s. 224-266.

${ }_{27}$ Zob. W. Windelband, Die Geschichte der neueren Philosophie, Bd. 2, Die Blüthezeit der deutchen Philosophie. Von Kant bis Hegel und Herbart, „II. Teil, Die Kantische Philosophie, § 61. Kants ästhetische Philosophie", s. 146-173. Zob. też uwagi A. J. Norasa w Historia neokantyzmu, s. 469-471.

28 Ibidem. Zob. też szersze uwagi w tej sprawie u A. J. Norasa w Historia neokantyzmu, s. 472. 
nał „syntezy Kanta z idealizmem niemieckim”, a zwłaszcza „syntezy z Heglem"29. Dodajmy, że w swoim wykładzie Twardowski sięgał też po ustalenia Kuno Fischera z Fichte und seine Vorgänger ${ }^{30}$, a także do jego Friedrich Wilhelm Joseph Schelling. Erstes Buch. Schellings Leben und Schriften $^{31}$. Prace te zawierają liczne informacje historyczne. Są idealną prezentacją życia i filozofii Fichtego oraz Schellinga. Dokonania Windelbanda, a także Fischera, stały się dla Twardowskiego optymalną formą zbliżenia filozofii Kanta z filozofią Hegla, przy jednoczesnej akceptacji wszelkich różnic zachodzących między nimi. Doprowadził on te zależności do stanu, w którym zaakcentowany został jednoczesny powrót do Kanta i do Hegla. Fischerowi chodziło ponadto o podtrzymanie zainteresowania jedną i drugą filozofia, a także o wskazanie na Fichtego i Schellinga jako ogniwa łączące te dwa ważne momenty w historii filozofii. Stanowiska te wpłynęły niewątpliwie na decyzję Twardowskiego o obraniu kierunku w dalszych jego badaniach.

W semestrze letnim 1903/1904 należy zwrócić też uwagę na zajęcia Wartenberga. Zainspirowany był on częściowo wspomnianym wykładem Twardowskiego, lecz postanowił zaprezentować studentom własne rozważania $O \dot{z} y$ ciu $i$ dziele Kanta. W tym samym jeszcze semestrze w ramach własnego seminarium filozoficznego podjął również po raz pierwszy we Lwowie lekturę i interpretację Wybranych, pomniejszych pism Leibniza. Twardowski natomiast wygłaszał wykład poświęcony Filozofii francuskiej wieku XIX. Prowadził również kontynuację zajęć seminaryjnych z lektury i interpretacji dzieł Hume'a i Kanta.

Wykład Twardowskiego o Filozofii francuskiej wieku XIX powstał jako dopełnienie, które ostatecznie nie weszło do wykładu z Rozwoju filozofii $w$ wieku XIX. Najważniejszym powodem wyprowadzenia tych rozważań poza wskazany wykład okazały się trudności związane z przygotowaniem wykładów o filozofii Hegla. Twardowski potrzebował bowiem więcej czasu na ich przygotowanie. Zrezygnował z prezentacji niedopracowanych własnych ustaleń o filozofii Hegla na rzecz przedstawienia wykładu z filozofii francuskiej. Innym jeszcze powodem była towarzysząca Twardowskiemu chęć zaprezentowania filozofii francuskiej jako filozofii narodowej. Dokładnie ten zamiar przedstawił $\mathrm{w}$ pierwszych zdaniach swojego wystąpienia. Czytamy tam: „Wiadomo, że wiele się mówi o filozofii narodowej. Rozumie się przez to specjalnie kierunek, specjalny duch, cechujący dążność i prace filozoficzne, poglądy i wy-

29 Zob. szersze uwagi w tej sprawie u A. J. Norasa w Historia neokantyzmu, s. 472-474 .

30 Zob. K. Fischer, Geschichte der neuern Philosophie, Bd. 5: Fichte und seine Vorgänger, Heidelberg 1869.

31 Zob. K. Fischer, Geschichte der neuern Philosophie, Bd. 6: Friedrich Wilhelm Joseph Schelling, Erstes Buch: Schellings Leben und Schriften, Heidelberg 1872. 
niki, właściwe danemu narodowi. Ktokolwiek się zastanawiał nad pojęciami filozofii narodowej, musiał mimo woli się zapytać, czy też do innych nauk można $\mathrm{w}$ tym samym znaczeniu i tym samym prawem dodać określenie »narodowy«. O matematyce narodowej, fizyce narodowej, jakoś się nie mówi. I to przeciwstawienie zaraz nam nasuwa ważną cechę dążeń filozoficznych. W filozofii silny udział pierwiastka podmiotowego, subiektywnego, pozwalającego Fichtemu powiedzieć o tym, jaką kto wyznaje filozofię, rozstrzyga to, jakim on jest człowiekiem. Ton narodowy charakter danej filozofii objawia się zatem oczywiście w pierwszym rzędzie w tych naukach filozoficznych, w których ów czynnik podmiotowy może wystąpić najsilniej. Więc w tworzeniu tzw. poglądów na świat, a jeszcze bardziej może w zależnych w znacznej mierze od nich poglądów na życie, poglądów etycznych. A znowu w obrębie tych działów filozofii narodowy charakter wystąpi tym silniej, im bardziej dany naród skłonny jest do nadania każdej rzeczy zabarwienia subiektywnego, im mniej umie być w tego i innego rodzaju kwestiach obiektywnym, przedmiotowym. Skąd to się bierze, że filozofia polska, w epoce swego dotychczas największego rozkwitu, ma tak wybitnie narodowy charakter, tj. uwydatnia potrzeby i dążności ogólnonarodowe, społeczno-polityczne. Ale jeszcze w innym kierunku ta cecha narodowości się objawia. Trudno upatrywać w tym cechę przypadkowa, że w Anglii przeważa w teorii poznania kierunek tak wybitnie empiryczny, w Niemczech aprioryczny, racjonalistyczny. Trudno przeoczyć, że w Niemczech najwyższy rozkwit filozofii nosi piętno idealistyczne, ani we Francji, ani w Anglii ten kierunek idealistyczny mimo pojedynczych przedstawicieli jakoś przyjąć się nie mógł. Dokładniejsze rozpatrywanie tych rzeczy, dotąd niestety nie przeprowadzone, pozwoliłoby niezawodnie wykryć wiele rzeczy nie mało ciekawych; ale już pobieżna znajomość dziejów filozofii wystarcza, by nas przekonać, że rozwój filozofii u każdego narodu odbywa się zgodnie z jego ogólnym charakterem narodowym, i że u każdego narodu jego filozofia tworzy mniej lub więcej odrębną całość" ${ }^{\prime 32}$. Poza tym Twardowski nie zamierzał w swoim wykładzie wchodzić bliżej w annały rewolucji francuskiej, czy też wykładać kwestie dotyczące encyklopedystów francuskich. Wiedział bowiem o tym, co wykładano na innych kierunkach na Wydziale Filozoficznym we Lwowie. W swoim zwyczaju informował studentów o tego typu wykładach. Okazją do tego były chociażby w semestrze zimowym i letnim 1901/1902 wykłady z historii, które we Lwowie prowadził Bronisław Dębiński. Wykładał on bliżej okoliczności Rewolucji francuskiej 1789-1795 (semestr zimowy 1901/1902) oraz Historię francuskiej rewolucji, II. część, Żyronda i Jakobinów (semestr letni 1901/1902). W tej sytuacji Twardowski uznał, że studenci, którzy pamiętają i chodzą na polecane zajęcia Dębiń-

32 Zob. Filozofia francuska wieku XIX, s. 1-2. 
skiego, są doskonale obeznani z tym tematem i zbyteczne jest powtarzanie tych kwestii. W swoim wykładzie z Filozofii francuskiej wieku XIX dał jedynie zarys dziejów tej filozofii. Wskazał źródła, z których wyrastał sensualizm, a także pokazał pewne istotne koncepcje związane $\mathrm{z}$ recepcją brytyjskiego empiryzmu oraz recepcją filozofii Kanta i Hegla.

W nowym roku akademickim 1904/1905 pojawiły się we Lwowie $\mathrm{d} w a$ niezależne od siebie wykłady z filozofii nowożytnej. Pierwszy z nich $\mathrm{w}$ semestrze zimowym wygłaszał Wartenberg. Były to jego autorskie uwagi ze Wstępu do filozofii i encyklopedii nauk filozoficznych. Wykład ten został powtórzony przez niego w roku akademickim 1909/1910 w semestrze zimowym i w kolejnych latach. Z kolei Wartenberg kontynuował swoje rozważania $O \dot{z} y c i u ~ i ~ d z i e l e ~ K a n t a$. Twardowski zaś przedstawiał swój wykład o filozofii Hegla. Były to de facto dwa cykle wykładów noszące wspólny tytuł: Filozofia Hegla ${ }^{33}$. Pierwszy odbywał się w semestrze zimowym 1904/1905 w wymiarze jednej godziny tygodniowo. Drugi zaś został wygłoszony w semestrze letnim 1904/1905 i był prezentowany przez dwie godziny tygodniowo. Był on kontynuacją wykładu z semestru zimowego 1904/190534. Razem, jak czytamy w nocie inwentarzowej w Archiwum Połączonych Bibliotek WFiS UW, IFiS PAN i PTF oraz Polskiej Akademii Nauk Archiwum w Warszawie, Archiwum Kazimierza Twardowskiego, odnotowuje się dwadzieścia dziewięć odczytów na temat filozofii Hegla ${ }^{35}$.

Trzeba też wspomnieć, że w semestrze letnim w roku akademickim 1904/1905 Wartenberg prowadził w ramach swojego seminarium filozoficznego regularną lekturę Berkeleya Rozmów pomiędzy Hylasem $i$ Filonousem. Zajęcia te kontynuował także w semestrze zimowym w następnym roku akademickim. Wygłaszał również wykład O etyce i este-

33 Filozofia Hegla, zima 1904/5, 1 godzina, lato 1904/5, 2 godziny. Obejmuje 29 odczytów od 21 października 1904 r. do 6 lipca 1905 r. 1. Semestr zimowy, treść 19 odczytów od 21 października 1904 r. do 31 marca 1905 r.: „Życie i filozofia Hegla do 1807 r.", k. 1-128. 2. Semestr letni, wtorek i czwartek, 7-8 rano, treść 10 odczytów od 16 maja 1905 r. do 6 lipca 1905 r.: „Życie i filozofia Hegla od 1807 r. do 1818 r.”, tekst niedokończony, k. 129-168, nr spisu inw., P. 13,1. Wykłady te opublikujemy w jednym z najbliższych numerów „Ruchu Filozoficznego” w 2018 roku.

34 Druga część wykładu Twardowskiego o Filozofii Hegla zakończyła się wprowadzeniem do filozofii prawa Hegla. Nie była kontynuowana z powodu zakończenia semestru letniego 1904/1905. Twardowski do niej nigdy później nie wrócił. Z zachowanych odręcznych notatek: Filozofii w XIX stuleciu (Kartezjusz) dowiadujemy się, że po końcowych fragmentach, po nakreśleniu rysów filozofii Kanta, Fichtego, Schellinga i Hegla, przewidywane były uwagi w sprawie rozwoju logiki w Polsce na podstawie uwag Struvego w Systematycznym wykładzie Logiki czyli nauki dochodzenia i poznania prawdy. Mogły one stanowić materiał badawczy dla zakończenia wykładu Twardowskiego o Filozofii Hegla. Ostatecznie jednak nie weszły w jego skład.

35 Wykłady te nie mają żadnej numeracji poza wprowadzoną przez Twardowskiego (wpis marginesowy z datą dzienną). 
tyce Kanta. Twardowski natomiast kończył w swoim seminarium filozoficznym wyższym lekturę i interpretację Kantowskich Prolegomenów.

W następnym roku akademickim 1905/1906 w semestrze zimowym $\mathrm{w}$ ramach seminarium filozoficznego Twardowski interpretował dzieło Locke'a Szkice o rozumie ludzkim ${ }^{36}$. Zajęcia te kończyły się wypracowaniem zaliczeniowym. $Z$ kolei Wartenberg kontynuował w semestrze letnim swój wykład o Etyce i estetyce Kanta oraz w ramach seminarium filozoficznego proponował lekturę i interpretację Descartesa Rozmyślań o zasadach filozofii. Zajęcia z Descartesa prowadził on również zimą następnego roku.

Rok akademicki 1906/1907 przyniósł ze sobą w ramach dzielonego przez Twardowskiego na grupy A i B seminarium filozoficznego wyższego (gr. B) lekturę i interpretację Kantowskiej Krytyki praktycznego rоzити. W semestrze letnim Twardowski czytał natomiast Uzasadnienie metafizyki moralności. Z kolei Wartenberg $\mathrm{w}$ semestrze zimowym tegoż roku prowadził wykład z Historii nowszej filozofii do Kanta, a w semestrze letnim wykładał Filozofię angielska od Bacona do Hume'a. W ramach seminarium filozoficznego podejmował zaś wspólną lekturę dobranych ustępów z dzieła Kanta Kritik der Urteilskraft i roztrzasanie jego estetyki. W tym samym semestrze Łukasiewicz wygłaszał dodatkowo wykład z Filozofii Leibniza i jej znaczenia aktualnego.

W semestrze zimowym i letnim 1907/1908 Twardowski studiował ze studentami własny przekład, dokonany z Łukasiewiczem, Hume’a $B a-$ dań dotyczacych rozumu ludzkiego. Wartenberg natomiast latem tegoż samego roku zajmował się Filozofia Spinozy.

Idąc dalej w naszym przeglądzie, dochodzimy do roku akademickiego 1908/1909. Twardowski powrócił wówczas do Kanta i zajmował się zimą i latem Krytyka czystego rozumu. Warte odnotowania są również kolejne zajęcia Wartenberga. W swoim seminarium filozoficznym omawiał on bowiem Etykę Spinozy księgi I i II. Z kolei Rubczyński proponował studentom zajęcia z Filozofii Dunsa Szkota i jego polskich zwolenników w XV wieku.

$36 \mathrm{~W}$ tamtym czasie nie dysponujemy polskim pełnym przekładem dzieła Locke'a. Niemniej pojawiają się polskie próby przekładu tego dzieła. Zob. chociażby Logika czyli myśli z Lokka o rozumie ludzkim wyjęte, przeł. A. Cyankiewicz, Kraków 1784 - luźny przekład fragmentów słynnego dzieła Locke’a. Trzeba też wspomnieć o próbach przekładu z 1921 roku Wł. M. Kozłowskiego. Dokonuje on tłumaczenia O rozumie ludzkim, tj. listu, ks. I i II z dzieła Locke'a oraz podaje najważniejsze wiadomości o Locke'u. Twardowski zaleca lekturę niemieckiego wydania dzieła: Versuch über den menschlichen Verstand, In vier Büchern. Uebersetzt und erläutert von Julius Hermann Kirchmann, Verlag von L. Heimann, Berlin 1872-1874. 
W semestrze zimowym roku akademickiego 1909/1910 Twardowski wygłaszał jednogodzinny wykład o Rozwoju filozofii nowożytnej do $K a n t a^{37}$. Powodem jego włączenia do zajęć dydaktycznych były przede wszystkim prowadzone $\mathrm{w}$ ramach seminarium filozoficznego analizy, polegające na systematycznej lekturze i interpretacji wskazanych już dzieł. Twardowski zdawał sobie sprawę, że liczba uczestników jego seminariów jest ograniczona. Chciał upowszechnić treść omawianych tam prac dla szerszej publiczności. Ponadto lektura wspomnianych dzieł w wielu przypadkach nastręczała licznych kłopotów interpretacyjnych. Wymagała stworzenia ogólnego zarysu dziejów filozofii nowożytnej. Twardowski nie był też zadowolony z zajęć, które prowadził Wartenberg z Bacona, Hume'a, Spinozy i innych filozofów. Nie chciał jednak ingerować w zakres jego filozoficznych kompetencji. Studenci informowali go jednak o pojawiających się w ramach spotkań u Wartenberga dylematach co do właściwego odczytania oraz zrozumienia prac Locke'a, Hume'a, czy też Berkeleya. Trudność ta powiększała się wraz z podjęciem przez nich lektury Krytyki czystego rozumu i Krytyki praktycznego rozumu oraz Uzasadnienia metafizyki moralności. Osobna grupa problemów wyłoniła się też po lekturze dzieł Descartesa.

Wprowadzenie przez Twardowskiego wykładu z Rozwoju filozofii nowożytnej do Kanta do własnych prac dydaktycznych miało też inny cel. Został on przygotowany i zaprezentowany zgodnie z dopracowywanym przez niego historycznym pojęciem filozofii. Jego pełne ujęcie Twardowski przedstawił po raz pierwszy nieco później podczas swojego odczytu w Sekcji Filozoficznej XI. Zjazdu przyrodników i lekarzy polskich w Krakowie dnia 18-22 lipca 1912 roku. Wygłosił wówczas krótką mowę w sprawie Historycznego pojęcia filozofii ${ }^{38}$. Podobne treści Twardowski przedstawił w swoim wykładzie z Rozwoju filozofii nowożytnej do Kanta. Przygotowując go, próbował niewątpliwie wydobyć istotne w swej treści „pojęcie filozofii jako wytworu ducha ludzkiego" ${ }^{39}$. Stał się mimowolnie bezstronnym uczestnikiem prezentowanych poglądów da-

37 „Rozwój filozofii nowożytnej do Kanta”, 1. „Cz. I. Zima 1909/10, 1 godzina tygodniowo". Tekst 14 wykładów od 22 października 1909 r. do 11 marca 1910 r. Obejmuje XVI i XVII w., k. I, 1-89, nr spisu inw. P. 15, 4. 2. Dalej cytowane jako Rozwój filozofii nowożytnej do Kanta.

38 Zob. K. Twardowski, Historyczne pojeccie filozofii. Odczyt wygłoszony w Sekcji Filozoficznej XI Zjazdu lekarzy i przyrodników polskich w Krakowie, dn. 18.7.1912. Drukowany w Księdze pamiątkowej XI. Zjazdu lekarzy i przyrodników polskich w Krakowie 18-22 lipca 1912, Nakładem Komitetu Gospodarczego, s. 90-92. Zob. też K. Twardowski, Historyczne pojęcie filozofii. Streszczenie odczytu wygłoszonego w Sekcyi Filozoficznej XI. Zjazdu przyrodników i lekarzy polskich w Krakowie, dnia 18 lipca 1912, w: idem, Rozprawy i artykuły filozoficzne, zebrali i wydali uczniowie, Lwów 1927, s. 427-428 .

39 Ibidem. 
nego myśliciela. Nigdy nie mówił jednak, że dany filozof popełnia jakiś błąd, czegoś nie dookreśla itd. Starał się zawsze wskazywać historię filozofii złożoną z „pojęć" i pojmować ją jako „wytwór ducha ludzkiego" 40 . Twardowski sięgał w tym względzie, za sprawą Władysława Mieczysława Kozłowskiego ${ }^{41}$, po wykład z historii nowszej filozofii (nowożytnej) profesora Uniwersytetu w Erlangen dra Richarda Falckenberga ${ }^{42}$. W skatalogowanym księgozbiorze Twardowskiego znajdujemy Hilfsbuch zur Geschichte der Philosophie seit Kant pisany właśnie przez Falckenberga, a wydany w Lipsku u Veita \& Company w 1899 roku ${ }^{43}$. Twardowski sięgnął też po pierwsze wydanie Falckenberga Geschichte der neueren Philosophie von Nikolaus von Kues bis zur Gegenwart (1886) ${ }^{44}$. Czytał polski przekład Historyi nowszej filozofii, który opublikował i przesłał mu wspomniany Kozłowski jeszcze w 1895 roku $^{45}$. Twardowski, uwzględniając wszystkie te inspiracje, zaczął przygotowywać w semestrze zimowym swój wykład z Rozwoju filozofii nowożytnej do Kanta. W tym momencie stało się dla niego ważne, aby w pierwszej kolejności jak najlepiej skorzystać z dokonań Falckenberga. Szukał w tym dziele odniesień i skojarzeń ze swoimi przemyśleniami, a przede wszystkim potwierdzenia własnych przekonań. Już pierwsze zdania z Historii nowszej filozofii Falckenberga zwróciły jego uwagę. Zauważył, co pięknie zostało zapisane we „Wstępie” do tej pracy, że

40 Ibidem.

41 Kozłowski najprawdopodobniej przesłał egzemplarz przetłumaczonej przez siebie pracy Falckenberga Twardowskiemu, z prośbą o opinię lub stosowną recenzję w prowadzonym przez niego „Przełomie”. Nie wiemy jednak, czy taka recenzja została przez Twardowskiego napisana i opublikowana. Kozłowski tłumaczy w tym czasie także inne prace niemieckich filozofów na język polski, między innymi Wundta, Wstẹp do filozofii (1902), Ribota, Psychologię w Niemczech (1902), czy też Simmela, Zagadnienia filozofii dziejów (1903).

42 Richard Falkenberg (1851-1920). Od 1872 roku studiował na Uniwersytecie w Jenie, a także na Uniwersytetach w Lipsku, Halle, Erlangen i Getyndze. W 1877 roku otrzymał tytuł doktora. Po habilitacji w 1880 r. był wykładowcą w Jenie. Siedem lat później został mianowany prof. nadzwyczajnym, a w 1889 otrzymał nominację na profesora filozofii na Uniwersytecie w Erlangen. Napisał kompleksową historię filozofii. Jego główne prace to: Grundzüge der Philosophie des Nicolaus Cusanus (Breslau 1880); Geschichte der neueren Philosophie von Nikolaus von Kues bis zur Gegenwart (1886); Hermann Lotze. 1. Teil: Das Leben und die Entstehung der Schriften nach den Briefen (Stuttgart 1901) i Kant und das Jahrhundert (Leipzig 1907).

43 Zob. Skatalogowany księgozbiór prof. Kazimierza Twardowskiego, w: Połączone Biblioteki WFiS UW, IFiS PAN i PTF oraz Polskiej Akademii Nauk Archiwum w Warszawie, Archiwum Kazimierza Twardowskiego, poz. 331.

44 Zob. R. Falckenberg, Geschichte der neueren Philosophie von Nikolaus von Kues bis zur Gegenwart, Leipzig: Veit \& Company, 1892.

45 Zob. R. Falckenberg, Historya nowszej filozofii, przeł. W. M. Kozłowski, Warszawa 1895 (bezpłatny dodatek do „Prawdy”), ss. 345. 
w żadnej umiejętności gruntowna znajomość jej historii nie ma takiego znaczenia, jak w filozofii. Na podobieństwo nauki dziejów zbliża się ona z jednej strony do wiedzy ścisłej, z drugiej ma wiele pokrewieństwa ze sztuką. Z pierwszą łączy ją praca metodyczna i cel poznania; z drugą intuicja i dążność do ogarnięcia rzeczywistości jednym spojrzeniem. Idee metafizyczne trudniej się utrwala, ale też trudniej zbić drogą doświadczalną niż hipotezy fizyczne. Mniej tedy zależne od wciąż postępującej naprzód znajomości faktów, systematy filozoficzne nie starzeją się tak prędko jak teorie przyrodnicze; mają one w sobie coś z wieczystej trwałości klasycznych dzieł sztuki, zachowują po wszystkie czasy pewna, chociażby względną wartość, pomimo wzajemnych sporów i gadania o przezwyciężonych stanowiskach ${ }^{46}$.

Idąc tym tropem, Twardowski czytał dalej, że „dzieje filozofii - to filozofia ludzkości, tego wielkiego osobnika, który, doskonalszy od organów, jakimi pracuje, może jednocześnie myśleć przeciwieństwami, a wyrównując sprzeczności i odkrywając nowe, drogą koniecznego i pewnego rozwoju poznania dąży do wszechobejmującej prawdy zbiorowej, której nie możemy przedstawić sobie dość bogatą i uczłonowaną"47. Stąd odkrył, że „Nie tylko optymizm i pesymizm, determinizm i nauka o wolności, ale także panteizm lub indywidualizm, idealizm lub materializm, nawet racjonalizm i sensualizm wyrastają ostatecznie z uczuciowości, a chociaż posługują się myślą jako środkiem, pozostają ostatecznie przedmiotem wiary, uczucia, postanowienia" ${ }^{\prime 4}$. Twardowski w określeniach Falckenberga dostrzegł zatem nie tyle eklektyzm, ile możliwość stanowienia o poglądach filozoficznych na drodze postępu. Sam Falckenberg konkludował w tej sprawie:

Postęp tu ukazuje się nie zawsze w wynikach, gdyż często postawienie pytania jest daleko ważniejsze niż odpowiedź na nie. Zagadnienie wyszczególnia się $\mathrm{w}$ pewnym kierunku lub przeciwnie, staje się rozleglejszym, rozkłada się i wysubtelnia; jeżeli wtedy grozi rozproszenie na drobiazgi, ukazuje się jakiś badacz genialny i zwraca umysły do kwestii zasadniczej. Taki postęp zagadnień, który wszędzie z pociechą dostrzec możemy, stanowi w niektórych pytaniach, dręczących ciągle serce ludzkie, jedyną trwałą zdobycz wysiłku stuleci ${ }^{49}$.

Nie wnikając w tym momencie w dalszą treść wykładu Falckenberga, pragniemy jedynie wskazać, że na podstawie jego wykładu Twar-

\footnotetext{
46 Ibidem, s. 1.

Ibidem, s. 2-3.

Ibidem, s. 3-4.

Ibidem, s. 4-5.
} 
dowski ustalił swoje węzłowe "pojęcie wytworu ludzkiego ducha" 50 . W rzeczonym wykładzie podążał zatem za Falckenbergiem, a czasem także śladem Diltheya. Była to niewątpliwie metoda jego postępowania. Polegała ona na „uwolnieniu się od wszelkiej powagi religijnej (reformacji) w sprawach naukowych”, "rozwoju całego szeregu nauk szczegółowych obok teologii i filozofii” oraz „możliwości wyłonienia w szeregu nauk filozoficznych ponownie epistemologii", po to, aby wskazać „przyczynę nowożytnego zwrotu metodologicznego, a zwłaszcza źródło nowych metod filozofowania" ${ }^{51}$. Za każdym razem starał się on uwzględniać charakterystyczny dla siebie genus proximum, tj. „możliwość wskazania pojęcia określającego bezpośrednio coś nadrzędnego w stosunku do innego" ${ }^{\prime 52}$. I można w tym względzie poszukiwać innych, znacznie lepszych jeszcze opracowań, lecz nie znajdziemy chyba żadnej, zwłaszcza w Polsce[?] historii filozofii, która by tak, jak rozważania Twardowskiego, właściwie i precyzyjnie wykładała samą filozofię. Jest on nie tylko mistrzem słowa mówionego, lecz arcymistrzem $\mathrm{w}$ historii filozofii, w wykładanych przez siebie pojęciach filozoficznych zawsze w konkretnym i wiadomym przeznaczeniu. Wiemy doskonale, że jeszcze dziś tryumfy święcą różne inne, zmaterializowane i po wielokroć wydawane historie filozofii. Słusznie dalej poważa się u nas Historię filozofii Władysława Tatarkiewicza, lecz nie jest ona dziełem wyłożonym metodą Twardowskiego. Znamy w tym względzie jego reakcję, "ten serdeczny i szczery uśmiech", gdy po latach Tatarkiewicz pokazał mu odbitki własnej, schodzącej właśnie z matryc drukarskich historii filozofii. Oznaczał on w tamtym momencie podziw i jednocześnie wspomnienie własnej z trudem wypracowanej metody historycznego przedstawiania pojęć filozofii. Twardowski, przyglądając się dziełu Tatarkiewicza, wiedział doskonale, że jego własnego pomysłu nikt w dalszym ciągu jeszcze nawet nie podjął. Nie zdawał sobie jednak sprawy, że chyba nikomu po nim nie udało się pójść tą drogą. I nie trzeba pisać i silić się w tym względzie na kolejne historie filozofii, trudno bowiem stworzyć coś po Twardowskim równie ważnego, co posiadałoby i niosłoby ze sobą taką właśnie konkretnie wypracowaną metodę ${ }^{53}$.

Wróćmy jednak do wykładu Twardowskiego. Jego cel i zadania, które stawiał przed sobą, udały się $\mathrm{w}$ pełni. Zainteresowanie ze strony

50 Zob. też K. Twardowski, Historyczne pojęcie filozofii, w: idem, Rozprawy i artykuły filozoficzne, s. 427-428.

${ }_{51}$ Zob. Rozwój filozofii nowożytnej do Kanta. Są to tytuły kolejnych fragmentów z jego wykładu.

52 Zob. też K. Twardowski, Historyczne pojęcie filozofii, w: idem, Rozprawy i artykuty filozoficzne, s. 427-428.

53 Por. K. Twardowski, Dzienniki, cz. II (1928-1936), do druku przygotował, wprowadzeniem i przypisami opatrzył R. Jadczak, Toruń 1997, nota z 1 czerwca, niedzieli 1930 roku, s. 134. 
słuchaczy było tak duże, że postanowił kontynuować swój wykład w semestrze letnim 1909/1910 ${ }^{54}$. Nie wiemy jednak, dlaczego Twardowski nie powtórzył swojego wykładu w kolejnych dwunastu latach własnej działalności filozoficznej. Być może stwierdził, że grono jego pierwszych słuchaczy w tym momencie zakończyło swoją podstawową edukację filozoficzną, a studenci, którzy zamierzali ją dopiero rozpocząć, nie byli jeszcze przygotowani do lektury dzieł z zakresu filozofii nowożytnej. Mogły temu towarzyszyć również inne względy. Wśród nich trzeba wskazać prowadzone przez Twardowskiego badania nad psychologią eksperymentalną czy też kontynuowane wykłady z logiki. Ten przeszło dwunastoletni okres przerwy w wykładach z filozofii nowożytnej spowodowany był wydarzeniami niezależnymi od działalności dydaktycznej. Była nim I wojna światowa, a później trudne warunki rozwoju życia naukowego i akademickiego w wolnej Polsce. Twardowski, prowadząc swoje wykłady z filozofii nowożytnej, zakładał ponadto milczącą wspólnotę między tym, co czytają inni i co interpretują na swoich zajęciach. Cykl wychowywania kolejnych adeptów filozofii trwał przeważnie około sześciu do siedmiu lat, licząc studia i rozpoczęte prace nad doktoratem. Student miał wówczas sposobność wyboru swoich zajęć. Niekoniecznie wszyscy musieli studiować u Twardowskiego. Należy zatem zwrócić uwagę nie tylko na ciągłość, ale również na sens powtarzalności wykładów Twardowskiego. Swoje wykłady uzależniał on bowiem nie tylko od własnych zapatrywań, lecz także od nadrzędnych akademickich planów kształcenia ${ }^{55}$.

I jeszcze jedna ważna sprawa. Pierwszy cykl wykładów Twardowskiego poświęcony filozofii nowożytnej w roku akademickim 1909/1910 nosił tytuł Rozwój filozofii nowożytnej do Kanta. Sugerował on przez to, że będzie wykładał filozofię nowożytną bez omówienia filozofii Kanta. Spowodowane było to z jednej strony trudnościami, jakie ona sama nosiła w sobie, choć już wówczas filozofia polska dysponowała ważnym przekładem Chmielowskiego Krytyki czystego rozumu, a zwłaszcza przedmową do tego dzieła, gdzie została przedstawiona jego geneza, która jeszcze dziś wydaje się obowiązująca przy braku innych, bardziej rzeczowych i dokładnych prezentacji. Istniały wówczas też przekłady innych prac Kanta, a mianowicie jeszcze przed publikacją polskiego tłumaczenia Krytyki czystego rozumu ukazał się polski przekład Kantow-

54 Zob. „Rozwój filozofii nowożytnej do Kanta”, cz. II. Lato 1909/10. 1 godzina tygodniowo". Obejmuje 3 wykłady od 12 maja 1910 r. do 16 czerwca 1910 r. Obejmuje okres od XVII w., k. I, 1-40. 2.1. „Uzupełnienia z II trymestru 1922/23” do powyższych wykładów, k. 8-10. 2.2. Notatki z historii filozofii dotyczące pelagianizmu, jansenizmu i J. Bohme, k. 26-40. Nr spisu inw. P.15, 5. Pol. 1909-1923. mszps, rkps 17 x $21 \mathrm{~cm}$. K II, 129 /numeracja oddzielna dla części 1 i 2/. Luźne.

55 Zob. I. Dąmbska, Filozofia na Uniwersytecie Jana Kazimierza we Lwowie, „Zeszyty Lwowskie" 1971, nr 2, s. 76-90. 
skich Prolegomenów do wszelkiej przyszłej metafizyki, która będzie mogła wystapić jako nauka. Twardowski w tej sytuacji postanowił nie prowadzić swojego wykładu o filozofii Kanta. Zajęcia z Kanta przeniósł on też, jak widzieliśmy, na własne seminaria filozoficzne. Proponował tam studentom lekturę i interpretację fragmentów z Krytyki czystego rozumu, Krytyki praktycznego rozumu, Uzasadnienia metafizyki moralności, czy też Prolegomenów. Dodajmy, że w zbiorach archiwalnych zachowało się sporządzone przez niego streszczenie tego ostatniego dzieła ${ }^{56}$. Lektura Kantowskich dzieł, zwłaszcza Krytyki czystego rozumu i Prolegomenów, prowadzona podczas seminarium wyższego, służyła też Twardowskiemu w przygotowaniach do obchodów Kantowskiego Jubileuszu w 1904 roku z okazji setnej rocznicy śmierci Kanta, a częściowo wiązała się z powołaniem do życia Polskiego Towarzystwa Filozoficznego we Lwowie. To właśnie podczas spotkań $\mathrm{w}$ ramach tego seminarium Twardowski wypracował założenia dla własnego wystąpienia inauguracyjnego, które wygłosił podczas zjazdu założycielskiego Polskiego Towarzystwa Filozoficzne$\mathrm{go}^{57}$. Pojawiają się w nim liczne odwołania do filozofii Kanta, a zwłaszcza propagowany jest pojęty po Kantowsku krytycyzm ${ }^{58}$. Filozofia Kanta, a zwłaszcza jej recepcja w obszarze polskiej myśli filozoficznej była wielokrotnie podnoszona i popierana przez Twardowskiego. Wspiera on wspomniane przekłady dzieł Kanta, tj. Krytyki czystego rozumu w tłumaczeniu Chmielowskiego, później też Prolegomenów w translacji Benedykta Bornsteina, czy również Uzasadnienia metafizyki moralności, które przekłada Wartenberg ${ }^{59}$. Asymilacja tej filozofii na gruncie polskiej filo-

56 Kant Prolegomena w streszczeniu, (prawdopodobnie z 1927 r.), mszps 17 x $21 \mathrm{~cm}$. , k. 14, po k. 16, k. A-H. luźne. 1. Tekst, k. 1-6. 2; „Anmerkung”, k. A-H. Nr spisu inw., P. 18,7 .

${ }_{57}$ Zob. przemówienie inauguracyjne K. Twardowskiego z okazji otwarcia Polskiego Towarzystwa Filozoficznego: Otwarcie Polskiego Towarzystwa Filozoficznego we Lwowie, „Przegląd Filozoficzny”, R. 7, 1904, z. 2, s. 239-243.

58 Informacje o krytycyzmie Kanta Twardowski zawdzięczał niewątpliwie Struvemu. Krytycyzm Kanta był omawiany w różnych jego pracach. Zob. zwłaszcza charakterystykę zawartą we Wstępie krytycznym do filozofii, Warszawa 1898, wyd. II poprawione. Zob. też jego rozważania Immanuel Kant oraz dziejowa doniosłość jego krytycyzmu, „Biblioteka Warszawska”, t. 3, 1904, s. 7. Zob. również artykuły A. Skórskiego, Krytycyzm Kanta wobec zagadnień życia, „Przegląd Filozoficzny”, R. 27, 1924, z. 3/4, s. 131-145 i M. Sobeskiego, Krytycyzm jako podstawa estetyki Kanta, „Literatura i Sztuka. Dodatek do «Dziennika Poznańskiego»", R. 6, nr 21 z 24 maja 1914 r., s. 321-324.

59 Twardowski wspierał w staraniach Piotra Chmielowskiego przy przekładzie Krytyki czystego rozumu, a podczas I Zjazdu Polskiego Towarzystwa Filozoficznego we Lwowie powierzył mu odczyt inauguracyjny. Zob. artykuł P. Chmielowskiego pt. Kant w Polsce, „Przegląd Filozoficzny”, R. 7, 1904, z. 4, s. 379-394. Twardowski wspomina także w swoich Dziennikach o pomyśle ponownego wydania Uzasadnienia metafizyki moralności. Zob. K. Twardowski, Dzienniki, cz. II: 1928-1936, do druku przygotował, wprowadzeniem i przypisami opatrzył R. Jadczak, Warszawa-Toruń 2002, s. 150 . 
zofii oznaczała dla Twardowskiego właściwe odczytanie krytycyzmu Kanta $^{60}$.

W semestrze zimowym 1909/1910 Twardowski rozpoczął w seminarium filozoficznym lekturę i interpretację rozprawy Schopenhauera O wolności woli ludzkiej w polskim przekładzie A. Stögbauera. Prowadził ją również w semestrze letnim. Obok wspomnianego wykładu Twardowskiego pojawił się jeszcze wówczas drugi wykład z zakresu filozofii nowożytnej. Wygłaszał go Wartenberg. Było to powtórzenie i kontynuacja rozważań ze Wstępu do filozofii i encyklopedii nauk filozoficznych. Wartenberg kontynuował również $\mathrm{w}$ ramach swojego seminarium zajęcia z Etyki Spinozy. Głos zabrał też Rubczyński, prowadząc zajęcia, na których proponował Wspólny rozbiór krytyki estetycznych pogladów Kanta zawarty w "Kalligonii" Herdera. Z kolei w semestrze letnim Twardowski kontynuował swój wykład z Rozwoju filozofii nowożytnej do Kanta, cz. II. Wartenberg natomiast wygłaszał wykład o Pogladach aksjologicznych Schopenhauera i Hartmanna i w ramach seminarium filozoficznego wykładał Lotzego zarys metafizyki.

W latach 1910/1911 w semestrze zimowym i letnim Twardowski $\mathrm{w}$ ramach swojego seminarium kontynuował lekturę i interpretację dzieł brytyjskich z filozofii nowożytnej. Czytał dzieło Hume'a, tj. Traktat o naturze ludzkiej, cz. I „O rozumie”"61. Zimą tegoż roku Wartenberg podjął wykład o Filozofii Kanta, kontynuował go również w semestrze letnim. W ramach seminarium filozoficznego czytał zaś Berkeleya Rzecz o zasadach poznania. Z kolei Rubczyński prowadził wykład Zarys dziejów nowszej estetyki od Kanta i proponował studentom Wspólna analize i porównanie pogladów estetycznych Schellinga i Hegla. Do tego jeszcze dochodzą zajęcia Łukasiewicza z Filozofii Bergsona. Latem zaś w tym samym roku akademickim Wartenberg $\mathrm{w}$ ramach swojego seminarium filozoficznego rozpoczął po raz kolejny lekturę i interpretację dzieła Descartesa. Były to popularne wówczas i często zalecane do czytania studentom Meditationes de prima philosophia.

${ }^{60}$ Fragment ten pokrywa się częściowo z tekstem książki: R. Kuliniak i D. Leszczyna, Spory wokót polskich przekładów dzieł Immanuela Kanta z lat 1795-1918, „Cz. I. Polemiki wokół dawnych polskich przekładów Kantowskich «Prolegomenów do wszelkiej przyszłej metafizyki, która będzie mogła wystąpić jako nauka»", s. 14-16.

${ }_{61}$ Twardowski, przy braku polskiego tłumaczenia tego dzieła, zalecał analizę i interpretację tekstu oryginału lub wydania niemieckiego David Hume's Traktat über die menschliche Natur (Treatise on human nature). Ein Versuch, die Methode der Erfahrung in die Geisteswissenschaft einzuführen. I. Teil. Über den Verstand. Übersetzt von E. Köttgen. Die Übersetzung überarbeitet und mit Anmerkungen und einem Register versehen von Theodor Lipps. Verlag von Leopold Voss, Hamburg und Leipzig, 1895. W tym czasie nie zalecał też czytania polskich prób przekładu tego dzieła Hume'a. Stawiał raczej na własną interpretację i dawał możliwość wykazania się studentom na podstawie lektury oryginału lub przekładu niemieckiego. 
W roku akademickim 1911/1912 Twardowski do swoich zajęć seminaryjnych wprowadził lekturę i interpretację wybranych pism Leibniza. Czytał Monadologię, a także fragmenty z Nowych rozważań dotyczacych rozumu ludzkiego, nad którymi sam pracuje teraz i później w latach 1921/1922 ${ }^{62}$. Dodajmy, że nad dziełem Leibniza Twardowski pracował też w latach 1925/1926. Najprawdopodobniej dołączyła wówczas do niego Izydora Dąmbska, która po II wojnie światowej wydała pełny przekład tego dzieła Leibniza ${ }^{63}$. Lekturę wybranych dzieł Leibniza Twardowski kontynuował też $\mathrm{w}$ semestrze letnim tego samego roku akademickiego. W semestrze zimowym swoje zajęcia prowadził też Wartenberg. Wygłaszał wykład o Etyce Kanta. Z kolei Łukasiewicz prowadził zajęcia z Zagadnienia poznania w filozofii nowożytnej.

W roku akademickim 1912/1913 w semestrze zimowym i letnim Twardowski powrócił do lektury i interpretacji Prolegomenów. Z kolei Wartenberg $\mathrm{w}$ ramach swojego seminarium filozoficznego $\mathrm{w}$ tym samym zakresie $w$ semestrach zimowym i letnim podjął lekturę $\mathrm{i}$ interpretację Etyki Spinozy, do której wracał sukcesywnie w kolejnych latach swojej działalności akademickiej. Ponadto prowadził wykład o Stosunku Kanta do metafizyki.

Dodatkowo w semestrze zimowym 1913/1914 Twardowski rozszerzył zakres lektur z filozofii nowożytnej o badania nad dziełem Bacona Novum Organum ${ }^{64}$. Kontynuował tę lekturę i interpretację także w seme-

62 Z okresu lwowskiego wykładów i seminariów (1921/1922) Twardowskiego pochodziła jego próba przekładu dzieła Leibniza Nowe rozprawy o rozumie ludzkim. Zachował się on w Archiwum Połączonych Bibliotek WFiS UW, IFiS PAN i PTF oraz Polskiej Akademii Nauk Archiwum w Warszawie, Archiwum Kazimierza Twardowskiego. Zob. 91. Nowe rozprawy o rozumie ludzkim. Tłumaczenia, recenzje, omówienia. Pol., fr. 1921, mszps., rkps dwóch rąk w tym K. T. 30 x 23 i mniej cm. K. 130/ numeracja oddzielna dla części 1/2 + koperta. Luźne. 1. „Przedmowa” - 2 egz.: rkps, mszps K. 1-44; 2 . „Księga pierwsza O pojęciach wrodzonych. Rozdział pierwszy Czy istnieją w umyśle ludzkim zasady wrodzone" - 3 egz.: 1 rkps. 2 mszps (oryginał i kopia) z odręcznymi poprawkami, k. 45-72, 74-120, brak k. 73. Nr spisu inw. T. 18, 31; 3. „Do Przekładu Leibniza”, luźne notatki do filozofii Leibniza, k. 1-11, nr spisu inw. T. 18, 32, AKT T-18-31, AKT T-18-32.

63 Zob. G. W. Leibniz, Nowe rozważania dotyczace rozumu ludzkiego, z oryginału francuskiego przełożyła i opatrzyła przypisami I. Dąmbska, wstępem poprzedził L. Kołakowski, t. I i II, Warszawa 1955. Dąmbska nigdzie w swoim przekładzie nie wskazuje na odniesienia do Twardowskiego. Symptomatyczne wydają się strony w przekładzie od 3 do 70. Wskazują duże podobieństwo do przekładu Twardowskiego. Sprawa ta jest ogromnie ciekawa. Brak o niej jednak jakichkolwiek wzmianek w literaturze przedmiotu. Wiemy jedynie, że Dąmbska studia u Twardowskiego zaczęła w 1922 roku po zdaniu matury. Niezwykle szybko zjednała też sobie sympatię Twardowskiego. Czy jednak miała wówczas w ręku przekład Twardowskiego dzieła Leibniza, tego nie wiemy.

64 Dzieło Bacona Twardowski polecał studentom w oryginale łacińskim. Korzystali oni również z licznych omówień dzieła i życia Bacona, w tym przede wszyst- 
strze letnim tegoż samego roku akademickiego. Latem tego samego roku Wartenberg wygłaszał z kolei swój wykład o Filozofii Schopenhauera.

Lata 1914/1915 to okres przerwy w wykładach i zajęciach akademickich spowodowany przez działania wojenne. Twardowski przeniósł wówczas Rektorat Uniwersytetu Lwowskiego do Wiednia i tam w zawężonym zakresie prowadził swoje zajęcia.

W roku akademickim 1915/1916 zajęcia z filozofii nowożytnej podjął Wartenberg. Prowadził on swoje seminarium filozoficzne. Czytał i interpretował dzieło Berkeleya Rozmowy Hylasa z Filonousem w semestrze zimowym i letnim.

Podobnie było w roku akademickim 1916/1917. Wówczas to w semestrze zimowym i letnim Wartenberg prowadził swoje seminarium filozoficzne, na którym omawiał Etykę Spinozy.

W roku akademickim 1917/1918 Twardowski wprowadził kolejną lekturę i interpretację, tym razem dzieła Descartesa Meditationes de prima philosophia ${ }^{65}$. Czytał tę pracę ze studentami podczas seminarium filozoficznego w semestrze zimowym i letnim. Natomiast Wartenberg zimą tegoż roku wygłaszał rzecz własną o Filozofii Schopenhauera. Latem zaś podjął wykład O stosunku Kanta do metafizyki. Kontynuował też wykład o Filozofii Schopenhauera, a w ramach seminarium filozoficznego czytał i interpretował Krytykę czystego rozumu.

Kolejne rozdanie akademickie 1918/1919 przyniosło ze sobą seminarium filozoficzne Twardowskiego poświęcone lekturze i interpretacji dzieła Hume'a, tj. Badań dotyczacych rozumu ludzkiego. Zajęcia te prowadził on w semestrze zimowym i letnim. Wartenberg ponownie wykładał Etykę Kanta. W semestrze zimowym swoje zajęcia na Wydziale prawa i umiejętności politycznych w zakresie nauk ogólnych prowadził Antoni Peretiatkowicz. Był to wykład z Filozofii społecznej J.J. Rousseau. W trzecim zaś trymestrze latem swoje seminarium filozoficzne z Etyki Spinozy kontynuował Wartenberg.

Z kolei w roku akademickim 1919/1920 na seminarium filozoficznym czytane było ponownie dzieło Hume'a Badania dotyczace rozumu ludzkiego. Jego lektura trwała zarówno w semestrze zimowym, jak i let-

kim z zalecanych przez Twardowskiego i niezwykle wysoko cenionych prac Fischera. Zob. K. Fischer, Franz Baco von Verulam. Die Realphilosophie und ihr Zeitalter, ed. F. A. Brockhaus, Leipzig 1856; Francis Bacon und seine Nachfolger. Entwicklungsgeschichte der Erfahrungsphilosophie. Zweite völlig umgearbeitete Auflage. F. A. Brockhaus, Leipzig 1875.

65 Podobnie, jak z Baconem, było z Descartesem. Twardowski zalecał lekturę oryginału, a zwłaszcza zob. edycję Charlesa Adama, Paula Tannery'ego (hrsg.): CEuvres de Descartes (11 Bände + Anhang), Léopold Cerf, Paris 1897-1913 (französisch und lateinisch), Bd. 7: Meditationes de prima philosophia, 1904. Zob. też wydane w 1885 roku Rozmyślania nad zasadami filozofii, przeł. K. Dworzaczek, red. H. Struve, „Biblioteka Filozoficzna", Skł. gł. w Księgarni E. Wendego i S-ki, Warszawa 1885. 
nim. Wartenberg natomiast kontynuował swoje seminarium filozoficzne z Etyki Spinozy.

W następnym roku akademickim 1921/1922 w obu semestrach Twardowski czytał ponownie w ramach własnego seminarium filozoficznego Descartesa Meditationes de prima philosophia. Z kolei Wartenberg wykładał Filozofię Schopenhauera, a w ramach seminarium filozoficznego Schopenhauera Die Welt als Wille und Vorstellung, zimą wybrane fragmenty, a latem tom II.

W roku akademickim 1922/1923 Twardowski postanowił ponowić swój wykład z Rozwoju filozofii nowożytnej ${ }^{66}$. Dwanaście lat przerwy $\mathrm{w}$ wykładaniu podstaw filozofii nowożytnej przyniosło pewne zmiany. Nie dotyczyły one jednak stylu wykładania. Twardowski pod tym względem postanowił pozostawić swój wykład w niezmienionej postaci i nadal wykładał historię filozofii według przyjętych wcześniej zasad. Towarzysząca tym wykładom idea historycznego ujęcia pojęć filozofii okazała się niezmiennie dobra. Twardowski rzadko zmieniał swoje przyzwyczajenia. Z czasem stał się natomiast jeszcze bardziej drobiazgowy i dokładny w poszukiwaniu oraz określaniu pojęć.

Cykl wykładów o Rozwoju filozofii nowożytnej wygłaszany w latach 1922/1923 miał za zadanie wchłonąć znaczną część wykładów z lat 1909/1910. Twardowski nie pozostał jednak bierny w stosunku do tego, co wygłaszał wcześniej. Postanowił uzupełnić niektóre kwestie wygłaszane przez siebie $\mathrm{w}$ roku akademickim 1909/1910. Planował wydanie tych dwóch wykładów drukiem po ich połączeniu. Ciekawy jest sam układ tego nowego wykładu. Zawierał on bowiem dołączony spis dzienny poszczególnych wykładów. Twardowski nie numerował tego wykładu osobnymi zapisami dat umieszczanych w stosownych miejscach na marginesach, lecz dokonywał na końcu osobnego przeglądu. Wykład o Rozwoju filozofii nowożytnej z roku akademickiego 1922/1923 był próbą prezentacji historii filozofii nowożytnej według wskazanego już pojęcia metody. Atutem tych rozważań była wykazywana w tekście wykładu literatura, z której starał się on korzystać. W wykładzie z 1909/1910 wskazywał on jedynie nieliczne pozycje, które pozostawały w kręgu jego zainteresowań. W wykładzie z 1922/1923 roku takich wskazań było znacznie więcej. Twardowski powracał też do analizy niektórych, dalszych wskazań Falckenberga. W pierwszej kolejności zwracał uwagę na to, że

${ }^{66}$ „Rozwój filozofii nowożytnej”. 1.,„Część I. Zima 1922/3. Wykład dwugodzinny". Obejmuje filozofię od XVI w. głównie R. Descartesa, A. Geulincxa, B. Spinozy, k. 1-81. 2. 14 poz. bibliograficznych o B. Spinozie, k. 82. 3. „Cz. II. Lato1922/3.” od XVII w. (B. Spinoza) do XVIII w. (J. Locke) k. 83-131. 4. Uzupełnienia i plan wykładów k. 132-139. Nr spisu inw. P.3,1. Pol. 1922-1923. maszynopis z odręcznymi i maszynowymi dopiskami. 17 x $21 \mathrm{~cm}$. K. 139. Luźne. 
wykład historii filozofii powinien się wystrzegać dwu ostateczności: bezładnego indywidualizmu oraz abstrakcyjnie logicznego schematyzmu. Dzieje filozofii nie składają się ani z następujących po sobie bez żadnego związku mniemań prywatnych i pomysłów genialnych, ani też z mechanicznie wywijających się typowych, w tej formie i kolei po sobie następujących stanowisk i zagadnień ${ }^{67}$.

Oznaczało to, że ,jednym z najwyższych celów dziejów świata jest wytworzenie filozofii; ale niezawodnie nie jest to cel jedyny. Stanowi on część wielkiego celu zbiorowego i nie należy się dziwić, że środki, którym powierzone jest jego urzeczywistnienie, nie jemu samemu jedynie służą że w działaniu swoim wywołują one często następstwa, które nie tylko są podrzędne dla rozwoju myśli filozoficznej, lecz wprost jej nieprzyjazne" $^{\prime \prime 6}$. Stąd też przyjmował, że

najważniejszym czynnikiem postępu filozoficznego jest oczywiście stan wiedzy $\mathrm{w}$ danej chwili, wynik pracy bezpośrednich poprzedników, a w stosunku do tych ostatnich należy znowu odróżniać stronę logiczną od psychologicznej. Często następca rozpoczyna swoją pracę umacniania, rozwijania i obalania pojęć nie w tym punkcie, którego by żądał historyk-budowniczy. W każdym razie dotychczasowe doświadczenia ucza, że nie można nigdy być dosyć ostrożnym w ustalaniu formalnych praw rozwoju myśli ${ }^{69}$.

Z tym też przekonaniem Twardowski przystąpił do pisania własnych wykładów. Nie wnikając $\mathrm{w}$ tym momencie $\mathrm{w}$ ich treść, należy zwrócić uwagę na jeden istotny moment. W wykładzie Twardowskiego, obok kwestii podlegających powtórzeniu, rozwinięciu bądź koniecznej $\mathrm{w}$ danym momencie kontynuacji, pojawiły się pewne elementy dodatkowe. Należał do nich niewątpliwie biogram filozofów epoki nowożytnej zwany przez niego tablicą synchroniczną najwybitniejszych filozofów XVI-XIX wieku. Twardowski kontynuował w tym momencie rozpoczęte przez siebie wcześniej przedsięwzięcie. Ułatwiało ono niewątpliwie historyczne przedstawienie filozofii poszczególnych myślicieli, wskazanie poprzedników i filozofów kontynuujących myśl danego myśliciela. Pozwalało też na wskazanie danej postaci na tle innych, a nawet jej konieczne wyróżnienie. $W$ tym względzie Twardowski znów zastosował własną metodę klasyfikacji historyczno-filozoficznej, gdzie kluczem okazały się wcześniej wprowadzone udogodnienia. Dodajmy jeszcze, że rozpoczynając swój drugi cykl wykładów z filozofii nowożytnej, Twardowski przyjął za Falckenbergiem konieczność wyeksponowania

67 Zob. R. Falckenberg, Historya nowszej filozofii, s. 5.

68 Ibidem.

69 Ibidem, s. 6 . 
motywu naczelnego. $W$ tym względzie podjął jedną z pierwszych w filozofii polskiej prób wyeksponowania podstaw filozofii Descartesa. Szedł tropem wspomnianego Falckenberga, który pisał, że „studiować dzieje filozofii od Kartezjusza, znaczy to studiować wstęp do filozofii dzisiejszej"70. Można się zastanowić: dlaczego Twardowski stawiał wówczas na Descartesa, a nie ufał i nie przedstawiał zasad filozofii Leibniza? Wybór w tym względzie był oczywisty i polegał na historycznym podejściu do filozofii. Leibniz, jak wcześniej Kant, został przeniesiony do analizy podczas zajęć seminaryjnych.

Ponadto w semestrze zimowym i letnim 1922/1923 Twardowski $\mathrm{w}$ ramach seminarium filozoficznego prowadził ponownie lekturę $\mathrm{i}$ interpretację Krytyki czystego rozumu. Z kolei Wartenberg wykłada Trzy krytyki Kanta. Jego wykład liczył aż cztery godziny lekcyjne tygodniowo. Latem z kolei Twardowski kontynuował swój wykład z Rozwoju filozofii nowożytnej, a Wartenberg wykładał ponownie Etykę Kanta.

W roku akademickim 1923/1924 Twardowski sięgnął po lekturę dzieła Jamesa Pragmatyzm. Prowadził ją zarówno w semestrze zimowym, jak i letnim. Ponadto w ramach seminarium filozoficznego rozpoczął roczną lekturę i interpretację dzieła Schopenhauera Ueber die viersache Wurzel des Satzes von zureichenden Grunde. Wartenberg z kolei w semestrze zimowym ponowił swój wykład o Etyce Kanta, a w semestrze letnim wygłaszał rzecz $O$ Kantowskiej nauce o paralogizmach $i$ antynomiach czystego rozumu.

Zimą roku akademickiego 1924/1925 Wartenberg wykładał Filozofie angielska od Bacona do Hume'a. W obu zaś semestrach 1925/1926 Twardowski prowadził lekturę i interpretację dzieła Leibniza Nowych rozważań dotyczacych rozumu ludzkiego. Z kolei Wartenberg w semestrze zimowym wygłaszał dwa wykłady: Metafizycy filozofii nowożytnej do Kanta i Stosunek Kanta do metafizyki. Ze swoim zajęciami dołączył wówczas do nich Roman Witold Ingarden. Proponował studentom ćwiczenia filozoficzne na podstawie Descartesa Medytacji o pierwszej filozofii. Był to wstęp do kolejnych ćwiczeń filozoficznych, tym razem poświęconych dziełu Edmunda Husserla Idee zu einen Philosophie.

W roku akademickim 1926/1927 Twardowski proponował lekturę i interpretację dzieła Brentana Versuch über die Erkenntnis. Wartenberg prowadził natomiast wykład porównawczy o Filozofii Spinozy i Leibniza, a $\mathrm{w}$ ramach seminarium filozoficznego powrócił do lektury i interpretacji dzieła Berkeleya Rozmowy Hylasa z Filonousem. Czytał ze studentami przekład niemiecki Richtera. W semestrze letnim wykład wygłaszał też Zygmunt Kukulski. Mówił o Pedagogice Pestalozziego.

W semestrze zimowym i letnim 1927/1928 Wartenberg wykładał Filozofię Kanta, a w ramach seminarium filozoficznego czytał i interpreto-

70 Zob. R. Falckenberg, Historya nowszej filozofii, s. 7. 
wał Kantowską Krytykę czystego rozumu. W tym samym czasie Kukulski prowadził wykład z Historii pedagogiki od połowy XVIII wieku.

Rok akademicki 1928/1929 przyniósł ze strony Twardowskiego zajęcia w seminarium filozoficznym, które poświęcił on lekturze i interpretacji G. E. Moore'a Zasad etyki. Wartenberg natomiast prowadził na swoim seminarium filozoficznym lekturę i interpretację Krytyki czystego rozumu. Z kolei Ingarden wykładał Poglady epistemologiczne empiryków angielskich, a w ramach własnych ćwiczeń filozoficznych podjął lekturę Berkeleya Rozprawy o zasadach poznania.

Kolejne zajęcia w roku akademickim 1929/1930, które podjął Wartenberg $\mathrm{w}$ ramach własnego seminarium filozoficznego, dotyczyły Etyki Spinozy. Ingarden zaś prowadził wykład o Pogladach epistemologicznych Hume'a oraz ćwiczenia filozoficzne z Rozważań logiki Lotzego.

Następny rok akademicki 1930/1931 przyniósł zimą wykład Wartenberga ze Wstęu do filozofii i encyklopedii nauk filozoficznych, a latem wykład z Filozofii angielskiej od Bacona do Hume'a. W obu semestrach podjął on również $\mathrm{w}$ ramach seminarium filozoficznego lekturę i interpretację Berkeleya Rozmów Hylasa z Filonousem. Ingarden natomiast w ramach ćwiczeń filozoficznych zajął się lekturą wybranych fragmentów z Locke’a Badań dotyczacych rozumu ludzkiego.

W roku akademickim 1931/1932 Wartenberg wykładał zimą Trzy krytyki Kanta, a w kolejnym roku akademickim 1932/1933 w semestrze letnim mówił o Dziejach filozofii po Kancie. Był to wykład w wymiarze pięciu godzin tygodniowo.

Z kolei w roku akademickim 1933/1934 Ingarden wykładał zimą Dzieje nowożytnego racjonalizmu, a na ćwiczeniach filozoficznych zimą i latem podjął lekturę Berkeleya Rozprawy o zasadach poznania. Prowadził też wykład w 1935/1936 roku w semestrze zimowym z Krytycyzmu Kan$t a$. Na ćwiczeniach filozoficznych czytał natomiast i interpretował Kantowskie Prolegomena.

Ostatnie przed wybuchem drugiej wojny światowej zajęcia z filozofii nowożytnej na Uniwersytecie Lwowskim prowadził Ingarden $i$ był to wykład z Dziejów filozofii nowożytnej.

\section{Zakończenie}

Kończąc przegląd wykładów z XVII, XVIII i XIX-wiecznej filozofii Twardowskiego i innych filozofów polskich na Uniwersytecie Lwowskim, trzeba jeszcze na chwilę zatrzymać na dwóch ważnych momentach. Wiemy już, że w szczególności zajęcia Twardowskiego w znacznej części polegały na lekturze dzieł filozoficznych. Czytano je w oryginale lub w dostępnych przekładach niemieckich, a także polskich tłumaczy. Miało to dać asumpt do uprawiania historii filozofii jako dziedziny nie- 
zbędnej i koniecznej przy wszelkich próbach dalszego filozofowania. Twardowskiemu i innym filozofom wykładającym we Lwowie udało się stworzyć nowy model uprawiania historii filozofii. Pisząc swoje wykłady, nie bali się sięgać do komentarzy prac źródłowych, które były trudne, a nawet kontrowersyjne. Chcieli przez to zyskać obraz dobrze tworzonych interpretacji do prac źródłowych. Ich wykłady o filozofii Bacona, Descartesa, Spinozy, Leibniza, Kanta, Fichtego, Schellinga, Hegla, czy też Schopenhauera pokazywały, na czym polega pluralistyczne podejście do filozofii. Była to przede wszystkim doskonała znajomość materiału źródłowego, który mógł następnie zostać poddany różnego rodzaju interpretacjom. Twardowski wiedział o tym doskonale. Znał sposób uprawiania historii filozofii przez wielkich filozofów na świecie. Sięgał po ich prace nie w celu poznania danej filozofii, lecz po to, by pokazać niegasnące źródło zainteresowania tymi ważnymi zagadnieniami z obszaru historii filozofii. Prace Windelbanda, Hayma, Fischera i Rosenkranza pokazują wreszcie, bez względu na istniejące wokół nich kontrowersje, czym są „,czyny historii filozofii"71.

\section{Bibliografia}

\section{a) Wykłady Kazimierza Twardowskiego:}

Filozofia Hegla, zima 1904/5, 1 godzina, lato 1904/5, 2 godziny. Obejmuje 29 odczytów od 21 października 1904 r. do 6 lipca 1905 r. 1. Semestr zimowy, treść 19 odczytów od 21 października 1904 r. do 31 marca 1905 r.: „Życie i filozofia Hegla do 1807 r.", k. 1-128. 2. Semestr letni, wtorek i czwartek, 7-8 rano, treść 10 odczytów od 16 maja 1905 r. do 6 lipca 1905 r.: „Życie i filozofia Hegla od 1807 r. do 1818 r.", tekst nie dokończony, k. 129-168, nr spisu inw., P. 13,1.

„Rozwój filozofii nowożytnej”. 1. „Część I. Zima 1922/3.Wykład dwugodzinny". Obejmuje filozofię od XVI w. głównie R. Descartesa, A. Geulincxa, B. Spinozy, k. 1-81. 2. 14 poz. bibliograficznych o B. Spinozie, k. 82. 3. „Cz. II. Lato 1922/3.” od XVII w. (B. Spinoza) do XVIII w. (J. Locke) k. 83-131. 4. Uzupełnienia i plan wykładów k. 132-139. Nr spisu inw. P.3,1. Pol. 1922-1923. mps z odręcznymi i maszynowymi dopiskami. 17 x 21 cm. K. 139. Luźne.

Twardowski K., Historyczne pojęcie filozofii. Odczyt wygłoszony w Sekcji Filozoficznej XI Zjazdu lekarzy i przyrodników polskich w Krakowie, dn. 18. 7. 1912. Drukowany w Księdze pamiątkowej XI. Zjazdu lekarzy i przyrodników polskich w Krakowie 18-22 lipca 1912.

${ }_{71}$ Zob. G. W. F. Hegel, Wykłady z historii filozofii, tłum. Ś. F. Nowicki, t. I, (Biblioteka Klasyków Filozofii) Warszawa 1994, s. 46. 
Twardowski K., Historyczne pojęcie filozofii. Streszczenie odczytu wygłoszonego w Sekcyi Filozoficznej XI. Zjazdu przyrodników i lekarzy polskich w Krakowie, dnia 18 lipca 1912, w: idem, Rozprawy i artykuty filozoficzne, zebrali i wydali uczniowie, Lwów 1927, s. 427-428.

Skatalogowany księgozbiór prof. Kazimierza Twardowskiego, w: Połączone Biblioteki WFiS UW, IFiS PAN i PTF oraz Polskiej Akademii Nauk Archiwum w Warszawie, Archiwum Kazimierza Twardowskiego, poz. 331.

„Rozwój filozofii nowożytnej do Kanta”, 1. „Cz. I. Zima 1909/10, 1 godzina tygodniowo". Tekst 14 wykładów od 22 października 1909 r. do 11 marca 1910 r. Obejmuje XVI i XVII w. k. I, 1-89, nr spisu inw. P. 15, 4. 2.

Filozofia w XIX. 1. "Rozwój filozofii w XIX. wieku, rok akademicki 1903/04, semestr zimowy, (obejmuje głównie: filozofię I. Kanta, J. G. Fichtego, F. W. J. Schellinga), k. 1-45, nr spisu inw. P. 1,3.

Przeglad krytyczny dziejów filozofii od czasów najdawniejszych do końca wieku XVIII, kurs letni 1896. Rok akademicki 1895/6, semestr letni, 3 godz. tygodniowo od 12-13 godz., rkps z licznymi odręcznymi i maszynowymi dopiskami i poprawkami, 21 x 17 cm., k. 210, luźne, 1. Tekst wykładu, k. 1-210; 2. Notatki do filozofii starożytnej, k. 211, nr spisu inw. P. 1,1.

Filozofia XIX w. Historia filozofii od XVII w. (Kartezjusz), (prawdopodobnie odczyt wygłaszany 14 marca 1902 r. we Lwowie, w sali obrad Rady Miejskiej w cyklu „Wiedza i Życie w XIX Stuleciu”), V, k. 61; Rękopis z odręcznymi dopiskami; Karty luźne; 1. Tekst odczytu, k. I-V, 1-60-2. Notatki, k. 61.

Filozofia francuska wieku XIX. Półrocze letnie 1903-1904. Tekst w języku polskim, k. 39, luźnych, formatu 21x17 cm. Pismo maszynowe, jednostronne, nr inw., P. 1,4.

Kant Prolegomena w streszczeniu, (prawdopodobnie z 1927 r.), mps 17 x $21 \mathrm{~cm}$, k. 14, po k. 16, k. A-H. luźne. 1. Tekst, k. 1-6. 2; „Anmerkung”, k. A-H. Nr spisu inw., P. 18,7.

Przemówienie inauguracyjne K. Twardowskiego z okazji otwarcia Polskiego Towarzystwa Filozoficznego: Otwarcie Polskiego Towarzystwa Filozoficznego we Lwowie, „Przegląd Filozoficzny”, R. 7, 1904, z. 2, s. 239-243.

\section{b) Źródła:}

AdamCh. , Tannery P. (hrsg.): CEuvres de Descartes (11 Bände + Anhang), Léopold Cerf, Paris 1897-1913 (französisch und lateinisch), Bd. 7: Meditationes de prima philosophia, 1904.

Berkeley G., Rzecz o zasadach poznania ludzkiego, przekład Feliks Jezierski, red. H. Struve, „Biblioteka Filozoficzna”, Skład główny w Księgarni E. Wendego i S-ki, Warszawa 1890.

Berkeley's Abhandlung über die Principien der menschlichen Erkenntnis, Erstdruck: Dublin 1710, Der Text folgt der ersten deutschen Übersetzung durch Friedrich Ueberweg von, Berlin 1869.

Condillac L'Abbé M., Logika czyli pierwsze zasady sztuki myślenia, przeł., uzup. i oprac. J. Znosko, Wilno 1802. 
Condillac L'Abbé M., Traité des Sensations, À Madame la Comtesse de Vassé par M. L'Abbé de Condillac, 1754, w: CEuvres complètes Condillac, édition Lecointe et Durey, 1821-1822.

David Hume's Traktat über die menschliche Natur (Treatise on human nature). Ein Versuch, die Methode der Erfahrung in die Geisteswissenschaft einzuführen. I. Teil. Über den Verstand. Übersetzt von E. Köttgen. Die Übersetzung überarbeitet und mit Anmerkungen und einem Register versehen von Theodor Lipps. Verlag von Leopold Voss, Hamburg und Leipzig 1895.

Descartes R., Rozmyślania nad zasadami filozofii, przeł. K. Dworzaczek, red. H. Struve, „Biblioteka Filozoficzna”, Skł. gł. w Księgarni E. Wendego i S-ki, Warszawa 1885.

Falckenberg R., Geschichte der neueren Philosophie von Nikolaus von Kues bis zur Gegenwart, Veit \& Company, Leipzig 1892.

Falckenberg R., Historya nowszej filozofii, tłum. W. M. Kozłowski, Warszawa 1895 (bezpłatny dodatek do „Prawdy"), ss. 345.

Fischer K., Geschichte der neuern Philosophie, Bd. 5: Fichte und seine Vorgänger, Heidelberg 1869.

Fischer K., Geschichte der neuern Philosophie, Bd. 6: Friedrich Wilhelm Joseph Schelling, Erstes Buch: Schellings Leben und Schriften, Heidelberg 1872.

Fischer K., Franz Baco von Verulam. Die Realphilosophie und ihr Zeitalter, ed. F. A. Brockhaus, Leipzig 1856.

Fischer K., Francis Bacon und seine Nachfolger. Entwicklungsgeschichte der Erfahrungsphilosophie. Zweite völlig umgearbeitete Auflage. F. A. Brockhaus, Leipzig 1875.

Hegel G. W. F., Wykłady z historii filozofii, tłum. Ś. F. Nowicki, t. I (Biblioteka Klasyków Filozofii), Warszawa 1994, s. 46.

Hume D., An Enquiry concerning Human Understanding, w: idem, Essays Moral, Political, and Literary by David Hume, ed. by T. H. Green and T. H. Grose, London 1898.

Hume D., Badania dotyczace rozumu ludzkiego, tłum. J. Łukasiewicz, K. Twardowski, Polskie Towarzystwo Filozoficzne, Lwów 1905.

Kondylak, Traktat o wrażeniach zmysłowych, z francuskiego przełożył A. Lange, red. H. Struve, „Biblioteka Filozoficzna”, Skład główny w Księgarni E. Wendego i S-ki, Warszawa 1887.

Leibniz G. W., Nowe rozprawy o rozumie ludzkim. Zachowuje się on w Archiwum Połączonych Bibliotek WFiS UW, IFiS PAN i PTF oraz Polskiej Akademii Nauk Archiwum w Warszawie, Archiwum Kazimierza Twardowskiego. Zob. 91. Nowe rozprawy o rozumie ludzkim. Tłumaczenia, recenzje, omówienia. Pol., fr. 1921, mps rkps. dwóch rąk w tym K. T. 30 x 23 i mniej cm. K. 130/ numeracja oddzielna dla części 1/2 + koperta. Luźne. 1. „Przedmowa” - 2 egz.: rkps, mszps K. 1-44; 2. „Księga pierwsza O pojęciach wrodzonych. Rozdział pierwszy Czy istnieją w umyśle ludzkim zasady wrodzone" - 3 egz.: 1 rkps, 2 mszps (oryginał i kopia) z odręcznymi poprawkami, k. 45-72, 74-120, brak k. 73, nr spisu inw. T. 18, 31; 3. „Do Przekładu Leibniza”, luźne notatki 
do filozofii Leibniza, k. 1-11, nr spisu inw. T. 18, 32, AKT T-18-31, AKT T-18-32.

Leibniz G. W., Nowe rozważania dotyczace rozumu ludzkiego, z oryginału francuskiego przełożyła i opatrzyła przypisami I. Dąmbska, wstępem poprzedził L. Kołakowski, t. I i II, Warszawa 1955.

Locke J., Versuch über den menschlichen Verstand, In vier Büchern. Uebersetzt und erläutert von Julius Hermann Kirchmann, Verlag von L. Heimann, Berlin 1872-1874.

Logika czyli myśli z Lokka o rozumie ludzkim wyjęte, przełożył Andrzej Cyankiewicz, Kraków 1784 - luźny przekład fragmentów słynnego dzieła Locke'a.

Windelband W., Die Geschichte der neueren Philosophie in ihrem Zusammenhange mit der allgemeinen Cultur und den besonderen Wissenschaften, Bd. 2, Die Blüthezeit der deutschen Philosophie. Von Kant bis Hegel und Herbart, Leipzig 1880 (2. Aufl. 1899).

Windelband W., Immanuel Kant. Zur Säkularfeier seiner Philosophie, w: idem, Präludien. Aufsätze und Reden zur Einleitung in die Philosophie, Freiburg i B. - Tübingen 1884.

Windelband W., Über die verschiedenen Phasen der Kantischen Lehre vom Ding-an-sich, „Vierteljahrsschrift für wissenschaftliche Philosophie”, Bd. 1, 1877 , s. 224-266.

Wykazy wykładów odbywać się majacych w C. K. Uniwersytet imienia Cesarza Franciszka I. we Lwowie. Skład Uniwersytetu i program wykładów z lat 1876$-1939$.

\section{c) Inne prace:}

„Słowo Polskie” nr 530 z 11 listopada 1904 roku (wyd. poranne), s. 1: „Odczyty i wykłady: Wykłady powszechne Dr. Twardowski: „Główne prądy w filozofii XIX w." (Sala XIV. Uniw.) o g. 71/2 ).

„Słowo Polskie” nr 542 z 18 listopada 1904 roku (wyd. poranne), s. 1: „Odczyty i wykłady: Wykłady powszechne Dr. Twardowski: Główne prądy w filozofii 19 w." (Sala XIV. Uniw.) o 7.30 w.

„Słowo Polskie” nr 554 z 25 listopada 1904 roku (wyd. poranne), s. 1: „Odczyty i wykłady: Wykłady powszechne Dr. Twardowski: Główne prądy w filozofii XIX w." (Sala XIV. Uniw. o 7:30).

„Słowo Polskie" nr 577 z 9 grudnia 1904 roku (wyd. poranne), s. 1: „Odczyty i wykłady: Wykłady powszechne Dr. Twardowski: Główne prądy w filozofii XIX w." (Sala XIV. Uniw. o 7:30).

„Słowo Polskie” nr 597 z 21 grudnia 1904 roku (wyd. poranne), s. 1: „Odczyty i wykłady: Wykłady powszechne Dr. Twardowski: Główne prądy w filozofii XIX w." (Sala XIV. Uniw. o 7:30).

„Słowo Polskie" nr 598 z 21 grudnia 1904 roku (wyd. popołudniowe), s. 5: „Wykłady powszechne. Zapowiedziany na dziś w "kalendarzu” numeru porannego wykład prof. dra Twardowskiego pt. „Główne prądy 
w filozofii XIX w." nie odbędzie się z powodu, iż już rozpoczęły się ferie świąteczne".

Chmielowski P., Kant w Polsce, „Przegląd Filozoficzny”, R. 7, 1904, z. 4, s. 379-394.

Dąmbska I., Filozofia na Uniwersytecie Jana Kazimierza we Lwowie, „Zeszyty Lwowskie", 1971, nr 2, s. 76-90.

Haratyk A., Uniwersytet Wakacyjny w Zakopanem jako jedno ze źródeł łaczności i edukacji kulturalnej Polaków w okresie zaborów, w: Edukacja wobec wielokulturowości. Księga jubileuszowa ofiarowana profesorowi Januszowi Sztumskiemu, red. M. Jakunowicz, K. Rędziński, Częstochowa 2002.

Jadczak R., Kazimierz Twardowski. Nota bibliograficzna, „Spis wykładów i seminariów Kazimierza Twardowskiego w Uniwersytecie Lwowskim", Toruń 1991, s. 59-77.

Kuliniak R. i Leszczyna D., Spory wokót polskich przekładów dzieł Immanuela Kanta z lat 1795-1918, „Cz. I. Polemiki wokół dawnych polskich przekładów Kantowskich »Prolegomenów do wszelkiej przyszłej metafizyki, która będzie mogła wystąpić jako nauka«, Wrocław 2015, ss. 221 (zawiera wybór tekstów dotyczący tej polemiki).

Kuliniak R. i Leszczyna D., Polskie badania nad filozofią brytyjskiego empiryzmu (lata 1760-1918), cz. I, "Studia z Historii Filozofii”, 2012, nr 3, s. 115-122.

Kurjata J., Towarzystwo Wyższych Kursów Wakacyjnych "Polska Nauka", w: Stownik polskich towarzystw naukowych, t. 2: Towarzystwa naukowe i upowszechniające naukę działające w przeszłości na ziemiach polskich, cz. 3, red. B. Sordylowa, Warszawa 2001, s. 504-506.

Noras A. J., Historia neokantyzmu, (Prace Naukowe Uniwersytetu Śląskiego w Katowicach 2965) Katowice 2012, „Część druga, Rozwój, 12. Szkoła badeńska, 12.1. Wilhelm Windelband", s. 453-462.

Skórski A., Krytycyzm Kanta wobec zagadnień życia, „Przegląd Filozoficzny”, R. 27, 1924, z. 3/4, s. 131-145.

Sobeski M., Krytycyzm jako podstawa estetyki Kanta, „Literatura i Sztuka. Dodatek do «Dziennika Poznańskiego»", R. 6, nr 21 z 24 maja 1914 r., s. 321-324.

Struve H., Immanuel Kant oraz dziejowa doniostość jego krytycyzmu, „Biblioteka Warszawska", 1904, t. 3.

Struve H., Wykład systematyczny logiki czyli Nauka dochodzenia i poznania prawdy, t. 1: Część wstępna, Warszawa 1870.

Twardowski K., Dzienniki, cz. II (1928-1936), do druku przygotował, wprowadzeniem i przypisami opatrzył R. Jadczak, t. I i II, Torun 1997.

Twardowski K., Rozprawy $i$ artykuty filozoficzne, Lwów 1927, s. 442-443 ("Główne prądy w filozofii wieku XIX. Program wykładów”).

Z. E., Uniwersytet wolny w Zakopanem, "Słowo Polskie”, nr 364 z 4 sierpnia 1904 roku, s. $2-3$ (korespondencja, datowana na 2 sierpnia 1904 r., sporządzona zostaje $\mathrm{w}$ trakcie trwania zajęć). 


\section{Streszczenie}

\section{Przegląd wykładów, ćwiczeń i seminariów akademickich Kazimierza Twardowskiego z filozofii nowożytnej}

Lwowskie wykłady akademickie Twardowskiego powinno się traktować jako kontynuację jego prac naukowych i dydaktycznych, rozpoczętych na uniwersytecie w Wiedniu, gdzie był prywatnym wykładowcą w latach 1894-1895. W owym czasie czynił wielokrotne starania o objęcie katedry filozofii na lwowskim uniwersytecie, które doprowadziły do uzyskania stanowiska profesora 1 października 1895 roku. Wykład inauguracyjny, wygłoszony 15 listopada 1895 roku, poświęcony był idei filozofii. Był on początkiem długiej aktywności naukowo-dydaktycznej. Wiele z jego wykładów nie ujrzało jeszcze światła dziennego i wciąż są dostępne jedynie w zbiorach trudnych do odczytania rękopisów. Wykłady akademickie Twardowskiego przygotowywane były bardzo starannie, zarówno gdy chodzi o ich formę, jak i treść, charakteryzują się one niezwykłą systematycznością. Prowadzone przez nas badania archiwalne i kwerendy biblioteczne cały czas przynoszą nowe informacje; wykłady, które odkryliśmy do tej pory, ukazują wszechstronną wiedzę Twardowskiego, jego dogłębne rozumienie poruszanych problemów, jasność języka oraz stylu.

\section{Stowa kluczowe}

Kazimierz Twardowski, lwowskie wykłady akademickie, filozofia nowożytna

\section{Summary}

\section{The Review of Kazimierz Twardowski's Acadamic Lectures, Classes, and Seminars on Modern Philosophy}

Twardowski's academic lectures in Lviv should be treated as a continuation of his scientific and didactic work, begun at the University of Vienna, where he lectured as a private lecturer in 1894-1895. At that time, he made numerous attempts to obtain a chair of philosophy at the University of Lviv. He received his professorship on November 1, 1895. His inaugural lecture, given on November 15,1895 , was devoted to the idea of philosophy. Since then, he started his longterm scientific and didactic activity. Most of his lectures have not yet seen the light of day and are still available only in archive collections, in hard-to-read manuscripts. Twardowski's academic lectures were conducted with great care, both in form and content. They are characterized by unprecedented systematism. According to our archival and library inquiries, while we are still discovering new facts and things, lectures we have already discovered present Twar- 
dowski's universal knowledge, his deep understanding of problems, clarity of language and style.

\section{Keywords}

Kazimierz Twardowski, academic lectures in Lviv, modern philosophy 